\title{
Elucidating $\mathrm{GABA}_{\mathrm{A}}$ and $\mathrm{GABA}_{\mathrm{B}}$ Receptor Functions in Anxiety Using the Stress-Induced Hyperthermia Paradigm: A Review
}

\author{
Christiaan H. Vinkers ${ }^{*}, 1$, John F. Cryan ${ }^{2}$, Berend Olivier ${ }^{1,3}$ and Lucianne Groenink ${ }^{1}$ \\ ${ }^{I}$ Division of Pharmacology, Utrecht Institute for Pharmaceutical Sciences (UIPS) and Rudolf Magnus Institute of \\ Neuroscience, Utrecht University, Sorbonnelaan 16, 3584 CA Utrecht, The Netherlands \\ ${ }^{2}$ School of Pharmacy, Department of Pharmacology \& Therapeutics, Alimentary Pharmabiotic Centre, University \\ College Cork, Cork, Ireland \\ ${ }^{3}$ Department of Psychiatry, Yale University School of Medicine, New Haven, USA
}

\begin{abstract}
Exposure to acute psychological or physical stress increases core body temperature (stress-induced hyperthermia, SIH) which is part of the autonomic stress response. SIH is used as a putative rodent anxiety paradigm in which anxiolytic drugs reduce the SIH response. The predictive validity of the SIH paradigm has proven to be good, making it suitable to detect the putative anxiolytic properties of drugs. So far, $\mathrm{GABA}_{\mathrm{A}}$ receptor agonists including benzodiazepines and hypnotics have proven to attenuate the SIH response. The $\mathrm{GABA}_{\mathrm{A}}$ receptor has been known to be closely involved in the acute stress response. Also, the recent development of compounds with selective efficacy for different $\alpha$ subunits at the benzodiazepine site of the $\mathrm{GABA}_{\mathrm{A}}$ receptor has renewed interest for the therapeutic potential of GABAergic drugs. Moreover, metabotropic $\left(\mathrm{GABA}_{\mathrm{B}}\right)$ receptor agonists reduce the $\mathrm{SIH}$ response. $\mathrm{GABA}_{\mathrm{B}}$ receptors are ubiquitously expressed in the central nervous system, and there is evidence for a role of the $\mathrm{GABA}_{\mathrm{B}}$ receptor in anxiety. Thus, both drugs acting on the $\mathrm{GABA}_{\mathrm{A}}$ and the $\mathrm{GABA}_{\mathrm{B}}$ receptor are generally able to attenuate the $\mathrm{SIH}$ response, and this review presents a detailed overview of the effects of both drug classes on the SIH response. As the GABA receptor family is diverse and complex, this paradigm may contribute to the elucidation of the putative effects of GABAergic drugs in emotional disorders such as anxiety and depression
\end{abstract}

Keywords: Model, drug screening, emotional fever, ionotropic, TP003, TPA023, zolpidem, zopiclone.

\section{THE SIH PARADIGM}

Exposure to acute psychological or physical stress robustly increases core body temperature (stress-induced hyperthermia, SIH) which is part of the autonomic stress response [1]. The fact that perceived stressful occasions (e.g. during a movie or prior to a sporting contest) increase body temperature in humans has been known for a long time [2, 3]. However, it was not until decades later that the SIH response was used as a putative rodent anxiety test when it was noticed that removing mice one by one from a grouphoused cage reproducibly increased body temperature of the last mouse compared to the first [4]. Later, this putative anticipatory anxiety test was improved to a singly-housed version in which the rectal temperatures are measured twice with an interval of 10 minutes (representing basal and stressed temperature values) [5]. More recently, the advent of telemetric systems that can accurately measure body temperature have led to increasing application of such systems in SIH experiments [6, 7].

The predictive validity of the SIH paradigm has proven to be good, making it suitable to screen putative anxiolytic drugs [1]. So far, drugs with anxiolytic properties such as

*Address correspondence to this author at the Division of Pharmacology, Utrecht Institute for Pharmaceutical Sciences and Rudolf Magnus Institute of Neurosciences, Utrecht University, Sorbonnelaan 16, 3584CA Utrecht, The Netherlands; Tel: +31 (0) 30253 1599; Fax: +31 (0) 30253 7900; E-mail: c.h.vinkers@uu.nl
$\mathrm{GABA}_{\mathrm{A}}$ receptor and $5-\mathrm{HT}_{1 \mathrm{~A}}$ receptor agonists as well as CRF receptor antagonists have proven to attenuate the SIH response, whereas non-anxiolytic dopaminergic or noradrenergic drugs generally do not affect the SIH response [8]. Moreover, acute administration of selective serotonin reuptake inhibitors and tricyclic antidepressants have no effect on the SIH response [8]. So far, chronic treatment with antidepressants has not resulted in altered SIH responses either.

Ionotropic $\left(\mathrm{GABA}_{\mathrm{A}}\right)$ and metabotropic $\left(\mathrm{GABA}_{\mathrm{B}}\right)$ receptors are ubiquitously expressed in the central nervous system $[9,10]$. The $\mathrm{GABA}_{\mathrm{A}}$ receptor $\left(\mathrm{GABA}_{\mathrm{A}} \mathrm{R}\right)$ has been known to be closely involved in the acute stress response and clinically relevant anxiolytic drugs such as benzodiazepines act on this receptor [11], whereas evidence for a role of the $\mathrm{GABA}_{\mathrm{B}}$ receptor in anxiety has more recently accumulated $[12,13]$. Both drugs acting on the $\mathrm{GABA}_{\mathrm{A}}$ and the $\mathrm{GABA}_{\mathrm{B}}$ receptor are generally able to attenuate the SIH response, and this review therefore presents a detailed overview on the effects of both drug classes in the SIH paradigm. SIH is an unconditioned, consistent and robust response, and the SIH test is easy to perform in acute and chronic setups. Moreover, the SIH paradigm is able to measure the effects of anxiolytic drugs on the SIH response as well as basal body temperature. As the GABA receptor family is diverse and complex, this model may contribute to the elucidation of the putative effects of GABAergic drugs in emotional disorders such as anxiety and depression. 


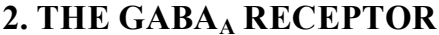

$\mathrm{GABA}_{\mathrm{A}} \mathrm{Rs}$ are ligand-gated ion channels that mediate fast inhibitory effects and are ubiquitously present in the central nervous system (Fig. 1), even though a typical central subunit distribution seems to exist [9, 14]. When GABA binds, chloride ions flow into the neuron, resulting in a hyperpolarization of the cell membrane. $\mathrm{GABA}_{\mathrm{A}} \mathrm{Rs}$ are found synaptically as well as extrasynaptically and are composed of five subunits with various possibilities per subunit $\left(\alpha_{1-6}, \beta_{1-3}, \gamma_{1-3}, \delta, \in, \theta\right.$ and $\left.\pi\right)$ that assemble to form a pentameric ligand-gated chloride channel. The $\mathrm{GABA}_{\mathrm{A}} \mathrm{R}$ displays a large molecular heterogeneity that depends on a variable subunit composition which ultimately determines physiological and pharmacological receptor properties and contributes to flexibility in signal transduction and modulation [11]. The most common subtype is a pentamer with $2 \alpha, 2 \beta$ and $1 \gamma$ subunit [15]. The fact that two different $\alpha$ subunits can co-exist in a single GABAA receptor adds to the variability of this receptor [16]. Different classes of pharmacological agents act on different sites on the $\mathrm{GABA}_{\mathrm{A}} \mathrm{R}$. Classic benzodiazepines bind to the $\mathrm{GABA}_{\mathrm{A}} \mathrm{R}$ benzodiazepine modulatory site between the $\alpha$ and $\gamma$ subunit. Other drug classes also bind to the $\mathrm{GABA}_{\mathrm{A}} \mathrm{R}$, such as alcohol, barbiturates and neurosteroids [17].
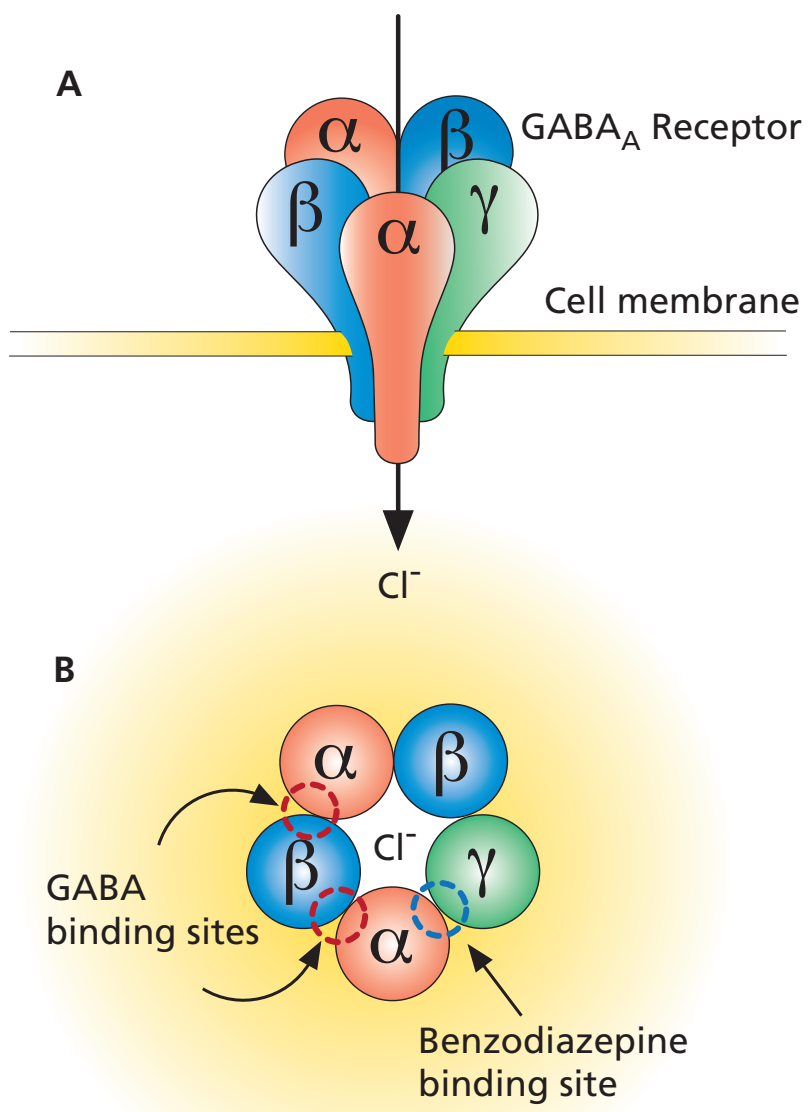

Fig. (1). Schematic representation of the $\mathrm{GABA}_{\mathrm{A}}$ receptor.

Classical (non-selective) benzodiazepines allosterically enhance the inhibitory actions of GABA by binding to $\mathrm{GABA}_{\mathrm{A}} \mathrm{Rs}$ that contain $\alpha_{1}, \alpha_{2}, \alpha_{3}$ or $\alpha_{5}$ subunits in combination with a $\beta$ and a $\gamma_{2}$ subunit. Recently, genetic and pharmacological evidence has indicated that $\alpha$ subunits may differentially contribute to the various classical benzodiazepines effects such as anxiolysis, dependence, anticonvulsant activity, sedation and amnesia [18, 19]. More specifically, the $\alpha_{1}$ subunit (present in over $50 \%$ of all $\mathrm{GABA}_{\mathrm{A}} \mathrm{Rs}$ ) is thought to mediate the sedative and amnestic actions of benzodiazepines, whereas $\alpha_{2}$ and $\alpha_{3}$ subunits (present in $10-20 \%$ of all $\mathrm{GABA}_{\mathrm{A}} \mathrm{Rs}$ ) probably mediate the anxiolytic action of benzodiazepines [20-22]. GABA $\mathrm{R} \alpha_{2}$ and $\alpha_{3}$ subunit involvement in the anxiolytic effects of benzodiazepines is derived from studies of knock-in mice that point to a role for the $\alpha_{2}$ subunit, whereas pharmacological experiments suggest a role for the $\alpha_{3}$ subunit. Currently, there is no good explanation for these apparent discrepancies.

The development of compounds with contrasting binding affinities for all $\alpha$ subunits has proven to be difficult as the benzodiazepine binding site is probably highly conserved between different $\alpha$ subunits. Thus, compounds that are affinity-selective in vitro are generally less or even nonselective in vivo, and finding compounds with differential $\alpha$ subunit affinity is a difficult goal to achieve. More recently, an alternative approach resulted in the development of compounds with selective efficacy for different $\alpha$ subunits of the $\mathrm{GABA}_{\mathrm{A}} \mathrm{R}$. Such drugs generally bind with equal affinity to all $\alpha$ subunits, but selectively modulate the activity of one or some of them (Fig. 2). Already earlier, partial agonists with lower efficacy at the $\mathrm{GABA}_{\mathrm{A}} \mathrm{R}$ compared to classical benzodiazepines such as bretazenil and abecarnil were developed. These drugs display overall lower efficacy at all $\alpha$ subunits and were thought to have decreased side effects, but resulted in severe sedation in humans [23]. Moreover, in contrast to the $\mathrm{GABA}_{\mathrm{A}} \mathrm{R}$ subtype specificity hypothesis, recently developed compounds with more $\alpha_{1}$ agonistic activity compared to the $\alpha_{2}, \alpha_{3}$ and $\alpha_{5}$ subunit appeared to be anxioselective in humans, indicating that the preclinical profile of $\mathrm{GABA}_{\mathrm{A}}$ ergic compounds does not always predict the clinical effects $[24,25]$. A possible explanation for these results could be that compounds only need moderate efficacy at $\alpha_{2}$ subunits to produce anxiolysis, whereas high efficacy at $\alpha 1$ subunits is required for sedation. However, these results show that $\mathrm{GABA}_{\mathrm{A}} \mathrm{R}$ pharmacology is complex and not fully understood. The concept that distinct $\mathrm{GABA}_{\mathrm{A}} \mathrm{R} \alpha$ subtypes generate the various clinical benzodiazepine effects remains valuable, and research on the $\mathrm{GABA}_{\mathrm{A}} \mathrm{R}$ in stress and anxiety processes therefore presents opportunities for the development of novel anxiolytic compounds.

In addition to the efforts that have been made on compounds targeting the $\mathrm{GABA}_{\mathrm{A}} \mathrm{R} \alpha$ subunits, the $\gamma$ subunit has also proven to influence benzodiazepine efficacy as the benzodiazepines binding site is located between the $\alpha$ and the $\gamma$ subunit [18]. Interestingly, exchanging the abundant $\gamma_{2}$ subunit for a $\gamma_{3}$ subunit resulted in decreased benzodiazepine affinity, whereas the hypnotic CL218,872 (with 17-fold selectivity for the $\alpha_{1}$ subunit [26]) displayed an increased affinity [27]. This suggests that a compound with $\alpha_{x} \gamma_{3}$ affinity over $\alpha_{x} \gamma_{2}$ affinity may constitute a novel target for the development of hypnotic or anxiolytic drugs.

In summary, the search for new anxiolytic drugs has focused on subunit specific $\mathrm{GABA}_{\mathrm{A}} \mathrm{R}$ agonists as such drugs 
are expected to dissociate anxiolytic from sedative effects. Prime candidates for non-sedating anxiolytic drugs appear to be compounds that lack activity at the $\alpha_{1}$-containing $\mathrm{GABA}_{\mathrm{A}} \mathrm{R}$ while modulating the $\alpha_{2}$ and/or $\alpha_{3} \mathrm{GABA}_{\mathrm{A}} \mathrm{R}$ subunit. These compounds could exert anxiolytic effects, whereas side effects which currently limit benzodiazepine use (among which sedation, ataxia, amnesia, alcohol potentiation, tolerance development and abuse potential) would be absent.

\section{Affinity and efficacy selectivity}

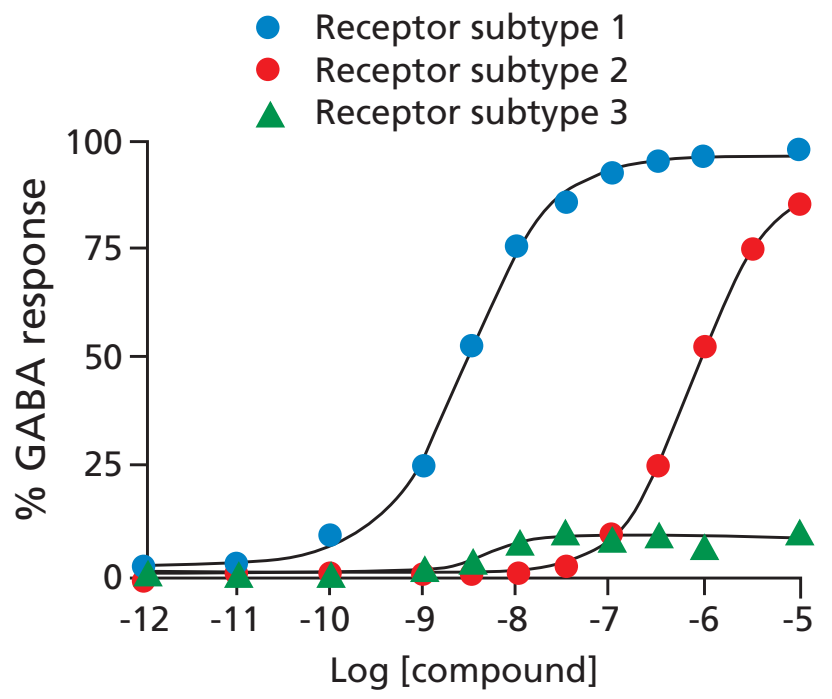

Fig. (2). Schematic summary of the GABA-enhancing properties (\% GABA response) of a fictional benzodiazepine-like compound with a reduced affinity for $\mathrm{GABA}_{\mathrm{A}}$ receptor subtype 2 and a reduced efficacy at $\mathrm{GABA}_{\mathrm{A}}$ receptor subtype 3 compared to subtype 1 .

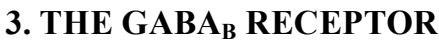

The $\mathrm{GABA}_{\mathrm{B}}$ receptor is a G-protein coupled receptor consisting of a heterodimer made up of two subunits,

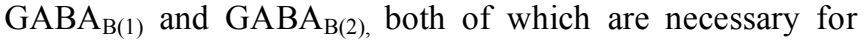
$\mathrm{GABA}_{\mathrm{B}}$ receptors to be functionally active [28] (Fig. 3). They are expressed both as presynaptic heteroreceptors and also postsynaptically, where they respectively modulate neuronal excitability. Heteroreceptors modulate the release of (excitatory) neurotransmitters, mainly via actions on presynaptic $\mathrm{Ca}^{+2}$ channels, and postsynaptic $\mathrm{GABA}_{\mathrm{B}}$ receptors activate slow inhibitory postsynaptic potentials via activation of inwardly-rectifying $\mathrm{K}^{+}$channels. $\mathrm{GABA}_{\mathrm{B}}$ receptors also function as autoreceptors on interneurons. Additionally, $\mathrm{GABA}_{\mathrm{B}}$ receptors are negatively coupled to adenylyl cyclase, through which they influence downstream molecular pathways [29].

There is a growing body of evidence indicating that $\mathrm{GABA}_{\mathrm{B}}$ receptors play a critical role in anxiety [30]. The prototypical $\mathrm{GABA}_{\mathrm{B}}$ receptor agonist, baclofen, has shown anxiolytic activity in some clinical settings. Baclofen reduced anxiety in post-traumatic stress disorder (PTSD) patients [31], in alcoholics following alcohol withdrawal [32, 33], in panic disorder [34] and in patients suffering from acute spinal trauma [35]. Baclofen has also demonstrated anxiolytic effects in several preclinical studies including ultrasonic vocalisation in rat pups [36], increased punished drinking [37], elevated plus maze [38] (but see [39]) and in the social interaction and elevated plus maze tests following withdrawal of dependent rats from either diazepam or alcohol [40-42].

Perhaps the strongest preclinical evidence to date for a role of $\mathrm{GABA}_{\mathrm{B}}$ receptors in anxiety was demonstrated by the phenotype of $\mathrm{GABA}_{\mathrm{B}}$ receptor-deficient mice. Deletion of either the $\mathrm{GABA}_{\mathrm{B}(1)}$ or $\mathrm{GABA}_{\mathrm{B}(2)}$ receptor subunits results in a complete loss of typical $\mathrm{GABA}_{\mathrm{B}}$ functions and induces a highly anxious phenotype in mice in exploratory-based tests of anxiety $[43,44]$. Furthermore, the $\mathrm{GABA}_{\mathrm{B}(1)}$ subunit is predominantly expressed as one of two isoforms: $\mathrm{GABA}_{\mathrm{B}(1 \mathrm{a})}$ or $\mathrm{GABA}_{\mathrm{B}(1 \mathrm{~b})}$, and deletion of these isoforms has differential effects on the acquisition and extinction of amygdala dependent conditioned aversive learning tasks [45].

Although studies with the $\mathrm{GABA}_{\mathrm{B}}$ receptor agonist, baclofen, have supported a role for $\mathrm{GABA}_{\mathrm{B}}$ receptors in anxiety its hypothermic, sedative and muscle-relaxant profile in a wide range of different species limit its applicability as a tool for behavioural research and as a therapy in psychiatry $[29,30,46]$. Recently, positive modulators of the $\mathrm{GABA}_{\mathrm{B}}$ receptor have been developed. CGP7930 and its aldehyde analogue CGP13501 were the first $\mathrm{GABA}_{\mathrm{B}}$ receptor positive modulators to be characterised in vitro [47]. A subsequent, structurally distinct chemical series which includes the more efficacious GS39783 were published shortly thereafter [48]. More recently two new classes have been identified racBHFF [49] and BHF177 [50, 51]. All of these compounds enhance both the potency and the maximal efficacy of GABA at $\mathrm{GABA}_{\mathrm{B}}$ receptors in vitro, via interactions with the 7-transmembrane domain of the $\mathrm{GABA}_{\mathrm{B}(2)}$ subunit, although they have little to no intrinsic action by themselves $[13,52]$. CGP7930, rac-BHFF and GS39783 have also demonstrated $\mathrm{GABA}_{\mathrm{B}}$ receptor positive modulation properties in vivo. CGP7930 and rac-BHF177 potentiated the loss-of righting effects of the $\mathrm{GABA}_{\mathrm{B}}$ receptor agonists baclofen and gamma-hydroxybutyrate (GHB) [49, 53], while in a microdialysis study, GS39783 potentiated the inhibitory effects of baclofen on forskolin-induced cAMP production in the rat striatum [54]. Of particular note, $\mathrm{GABA}_{\mathrm{B}}$ receptor positive modulators demonstrated anxiolytic profile in multiple rodent tests [13,49] without showing the motor impairing hypothermic or cognitive impairing actions that are characteristic of full $\mathrm{GABA}_{\mathrm{B}}$ receptor agonists $[13,43$, 55].

\section{EFFECTS OF GABA ${ }_{A}$ ERGIC DRUGS ON THE SIH RESPONSE}

\subsection{Benzodiazepine Site Ligands}

\subsubsection{Classical Benzodiazepines}

Classical benzodiazepines (among which chlordiazepoxide, diazepam, oxazepam, nitrazepam and alprazolam) dose-dependently reduce the SIH response, and, at higher doses, also reduce basal body temperature in rodents [1, 8]. So far, all benzodiazepines that have been studied in the original group-housed and the singly-housed SIH paradigm reduce the SIH response (Table 1). Therefore, studies that aim to assess the anxiolytic effects of different drug classes via the SIH paradigm often use benzodiazepines 


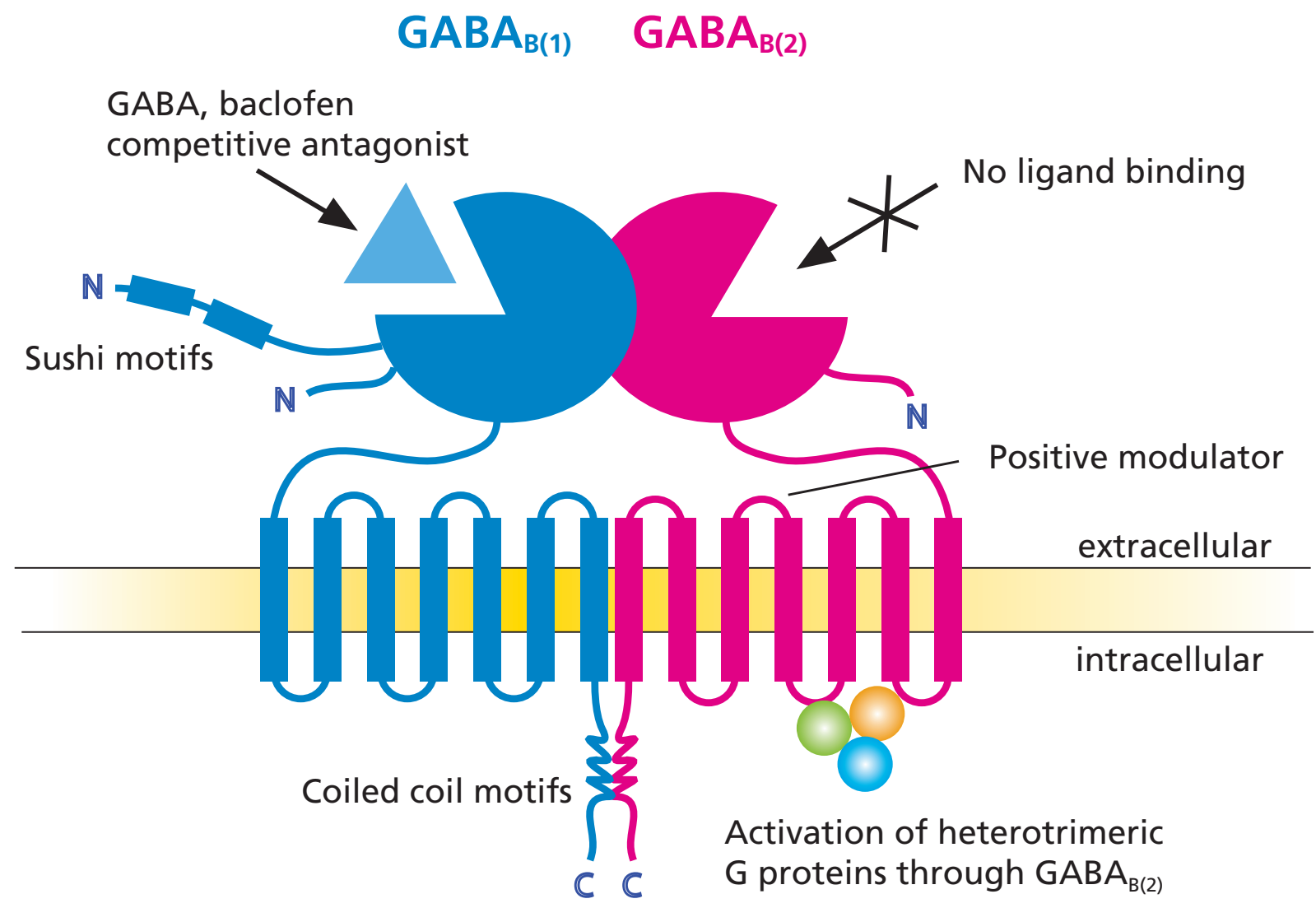

Fig. (3). Schematic representation of the $\mathrm{GABA}_{\mathrm{B}}$ receptor.

as a positive reference compound [56-58]. A typical example of the effects of the classical benzodiazepine diazepam on the SIH response in mice is shown in Fig. (4A). The SIH response is significantly decreased in drug-treated mice compared to vehicle-treated animals (one-way ANOVA with $\mathrm{T}_{1}$ and $\mathrm{T}_{2}$ as within-subject factor $(\mathrm{SIH})$ and treatment as between-subject factor, diazepam $\mathrm{x}$ SIH interaction $\mathrm{F}_{2,26}=3.27, \quad \mathrm{p}<0.05$ ). Moreover, diazepam significantly reduced basal body temperature at both doses (main diazepam effect $\mathrm{F}_{1,26}=15.67, \mathrm{p}<0.001$ with Dunnett's multiple comparison as post-hoc test). As classical benzodiazepines bind to $\alpha_{1}, \alpha_{2}, \alpha_{3}$ and $\alpha_{5}$ subunits [59,60], their effects on both the SIH response and basal body temperature are mediated via these subunits. Flumazenil (Ro 15-1788), a silent non-selective $\mathrm{GABA}_{\mathrm{A}} \mathrm{R} \alpha$ subunit antagonist, dose-dependently reversed the diazepam effects on the SIH response and basal body temperature in mice [61]. This illustrates the close involvement of the $\mathrm{GABA}_{A} \mathrm{R}$ $\alpha$ subunit in the benzodiazepine action on the SIH response as repeatedly has been shown that flumazenil does not influence the SIH response or basal body temperature levels [61-63].

\subsubsection{Benzodiazepine Agonists}

If $\mathrm{GABA}_{\mathrm{A}} \mathrm{R} \alpha$ subunits indeed differentially contribute to the various effects of classical benzodiazepines, the question remains how more selective drugs for these $\mathrm{GABA}_{\mathrm{A}} \mathrm{R}$ subtypes influence the SIH response and body temperature. So far, a number of drugs with $\alpha$ subtype selective activity have been tested in the SIH paradigm (Table 3). Zolpidem, with 5-10 fold more selectivity for $\alpha_{1}$ subunits compared to $\alpha_{2} / \alpha_{3}$ subunits [64], generally causes hypothermia without attenuating of the SIH response, indicating that the $\mathrm{GABA}_{\mathrm{A}} \mathrm{R}$ $\alpha_{1}$ subunit is not directly involved in anxiolytic effects but plays a role in thermoregulatory processes. In rats, zolpidem reduced the SIH response, but this was most likely the result of strong hypothermic effects on basal body temperature that disturbed physiological homeostatic mechanisms [65]. The hypothermic effects of zolpidem in mice are illustrated in Fig. (4B, main zolpidem effect $\mathrm{F}_{4,72}=83.24, \mathrm{p}<0.001$ ). Zolpidem also affected the SIH response (zolpidem x SIH interaction $\left.\mathrm{F}_{4,72}=27.81, \mathrm{p}<0.001\right)$. The apparent increase of the SIH response at lower doses is caused by a general body temperature reduction, allowing the SIH response to increase as the maximum body temperature is limited due to ceiling effects. At the highest dose, the reduction of the SIH response can be explained by the strong hypothermic and not necessarily anxiolytic effects of zolpidem. However, zolpidem may demonstrate less $\alpha_{1}$ subunit selectivity in vivo compared to in vitro studies using recombinant receptors, and it is possible that zolpidem may exert anxiolytic effects and reduce the SIH response in vivo via $\alpha_{2 / 3}$ subunits [66]. L838,417 is a compound with comparable affinity for the $\alpha_{1,2,3,5}$ subunits, but with no efficacy at the $\alpha_{1}$ subtype and partial agonistic efficacy at $\alpha_{2}, \alpha_{3}$ and $\alpha_{5}$ subtypes [21]. In three different mouse strains, L838,417 dose-dependently reduced the SIH response without affecting basal body temperature [63], indicating that the SIH response and basal 

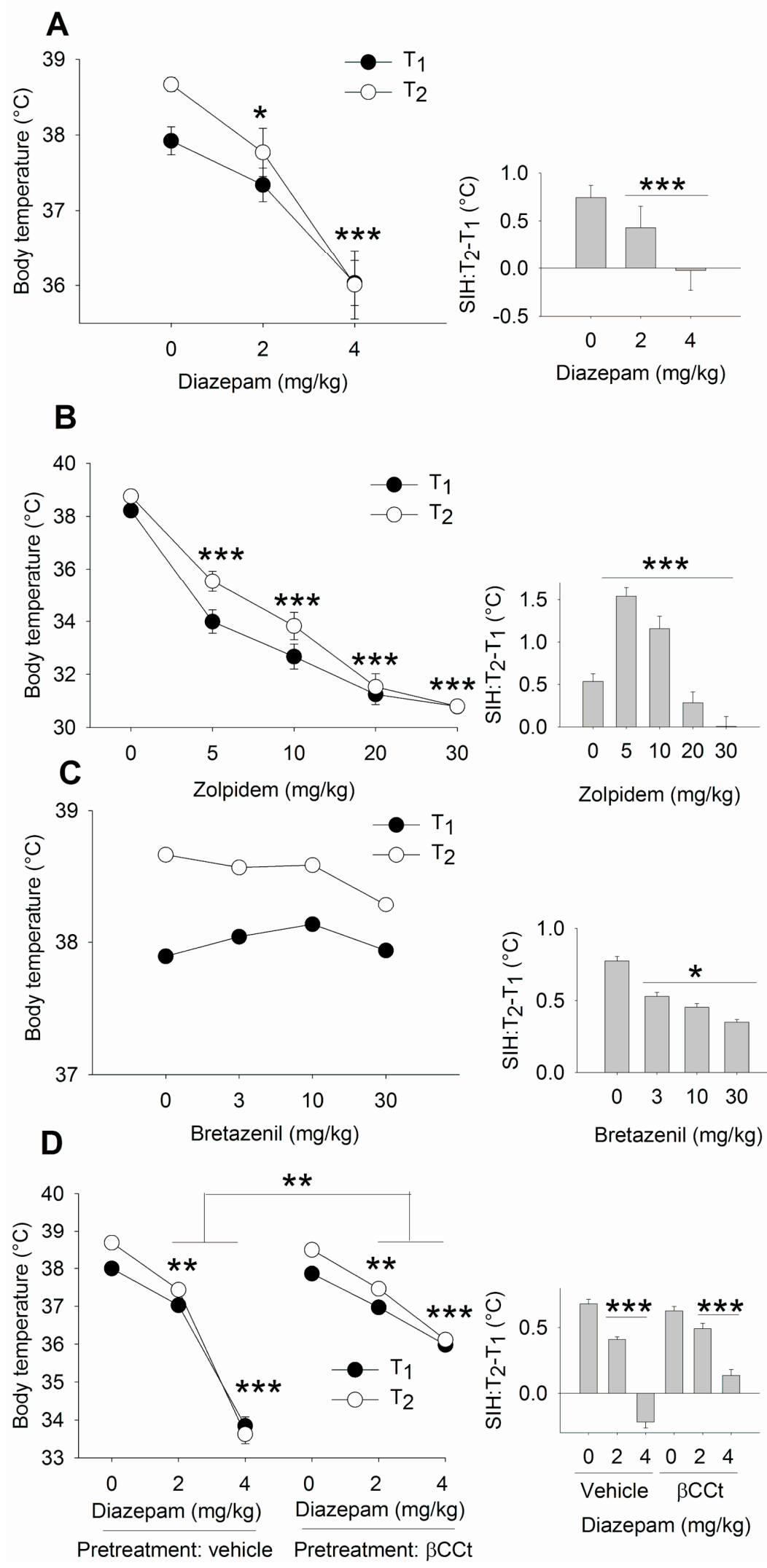

Fig. (4). Effects of non-subunit selective classical $\mathrm{GABA}_{\mathrm{A}}$ receptor agonist diazepam (A), the partial GABA $\mathrm{A}_{\mathrm{A}}$ receptor agonist bretazenil (B), the $\mathrm{GABA}_{\mathrm{A}}$ receptor $\alpha_{1}$ subunit-selective agonist zolpidem $(\mathbf{C})$ and the combination of diazepam and GABA $\mathrm{A}_{\mathrm{A}}$ receptor $\alpha_{1}$ subunit antagonist $\beta C C t$ (D) on the SIH response in $129 \mathrm{~Sv} / \mathrm{Ev}$ mice. ${ }^{*}: \mathrm{p}<0.05 ;{ }^{*}: \mathrm{p}<0.01 ; * * * \mathrm{p}<0.001$. 
body temperature can be independently altered depending on the drug properties. A putative role for the $\mathrm{GABA}_{\mathrm{A}} \mathrm{R} \alpha 3$ subunit in the $\mathrm{SIH}$ response anxiety was confirmed using the $\mathrm{GABA}_{\mathrm{A}} \mathrm{R} \alpha 3$ subunit agonist TP003 that attenuated the SIH response without affecting basal body temperature levels in both rats and mice $[20,65]$. Recently, we tested an essentially $\alpha 5$ selective compound which neither affected the SIH response nor caused hypothermia (unpublished data). This confirmed that activation of the $\alpha_{5}$ subunit is not essential for anxiolytic effects of classical benzodiazepines. There is increasing evidence for a role of the $\alpha_{5}$ subunit in cognitive processes however [67], and as a result, inverse $\alpha_{5}$ subunit agonists are being developed as cognition enhancers [68]. The low efficacy positive $\mathrm{GABA}_{\mathrm{A}} \mathrm{R}$ modulator bretazenil was found to be ineffective in the SIH paradigm in NMRI mice [61]. The marginal effects of bretazenil on either the SIH response or basal body temperatures were confirmed in $129 \mathrm{~Sv} / \mathrm{Ev}$ mice (main bretazenil effect $\mathrm{F}_{3,61}=0.82, \mathrm{p}=0.49$, NS, Fig. 4C). Interestingly, bretazenil significantly reduced the $\mathrm{SIH}$ response in this strain (bretazenil $\mathrm{x}$ SIH interaction $\left.\mathrm{F}_{3,61 .}=2.70, \mathrm{p}=0.05\right)$. These results are in line with previous research that showed an excellent non-sedating preclinical profile for this drug [69], even though later clinical studies showed that bretazenil caused sedation [23].

\subsubsection{Benzodiazepine Antagonists}

Based on these results, we hypothesize that the $\alpha_{2}$ and/or the $\alpha_{3} \mathrm{GABA}_{\mathrm{A}} \mathrm{R}$ subunit is involved in the attenuation of the $\mathrm{SIH}$ response, whereas $\mathrm{GABA}_{\mathrm{A}} \mathrm{R} \alpha 1$ subunit activation results in hypothermia. If hypothermia and sedation are both the result of $\mathrm{GABA}_{\mathrm{A}} \mathrm{R} \alpha 1$ subunit activation, an absence of lower body temperatures after drug administration may indicate reduced sedative side effects. To test this hypothesis, we combined the classical benzodiazepine diazepam and the hypnotic zolpidem with the $\alpha_{1}$ subunit antagonist $\beta C C t$ in rats [65] (Table 2). $\beta C C t$ is a compound with high affinity for the $\mathrm{GABA}_{\mathrm{A}}$ receptor $\alpha_{1}$ subunit compared to the $\alpha_{2}, \alpha_{3}$, and $\alpha_{4}$ subunits and with comparable low efficacy at all $\alpha$ subunits [70]. We found that administration of $\beta \mathrm{CCt}$ alone had no effect on either basal body temperature or novel cage-induced temperatures. However, prior injection with $\beta C C t$ antagonized hypothermic effects of both diazepam and zolpidem. We replicated this finding in mice (Fig. 4D, unpublished results). Again, $\beta C C t$ was able to reduce the diazepam-induced hypothermia (diazepam effect $\mathrm{F}_{2,64}=34.17$, $\mathrm{p}<0.001$; $\beta \mathrm{CCt} \mathrm{x}$ diazepam interaction $\mathrm{F}_{2,64}=5.38, \mathrm{p}<0.01$ ) without affecting the diazepam effects on the $\mathrm{SIH}$ response (diazepam $x \mathrm{SIH}$ interaction $\mathrm{F}_{2,64}=12.05, \mathrm{p}<0.001$; Diazepam $\mathrm{x} \beta \mathrm{CCt} \times \mathrm{SIH}$ interaction $\mathrm{F}_{2,64}=2.41, \mathrm{p}=0.10$, NS). $\beta C \mathrm{Ct}$ alone did not affect the SIH response $\left(\beta C C t \times \mathrm{SIH}\right.$ interaction $\mathrm{F}_{1,64}=0.23$, $\mathrm{p}=0.64$, NS). This supports the hypothesis that different $\mathrm{GABA}_{\mathrm{A}} \mathrm{R} \alpha$ subunits are responsible for $\mathrm{SIH}$ attenuation and hypothermia after benzodiazepine administration [65].

\subsubsection{Inverse Benzodiazepine Agonists}

Recently, we showed that the inverse benzodiazepine agonist F7142 indeed resulted in hypothermia in rats, although only a high dose $(15 \mathrm{mg} / \mathrm{kg})$ was used (Fig. 5, unpublished results). However, acute administration of the inverse benzodiazepine agonists pentylenetrazole and FG7142 did not result in an increased SIH response (Table 3).
Inverse benzodiazepine agonists allosterically decrease the binding of GABA and negatively influence constitutive $\mathrm{GABA}_{\mathrm{A}} \mathrm{R}$ activity. These compounds display anxiogenic effects in various animal models of anxiety [71, 72]. Putative anxiogenic drugs generally do not increase the autonomic $\mathrm{SIH}$ response in preclinical studies, suggesting that increased anxiety levels are not automatically accompanied by higher autonomic stress responsivity. Although anxiogenic compounds are considered to heighten subjective anxiety levels, tachycardia in anxious people depends on the situation and diagnosis, and a more avoiding personality is associated with reduced heart rate responses [73]. Moreover, patients with panic disorder (PD) display comparable physiological responses to healthy controls, even though they experience more frequent distress, suggesting that the perception of stress in anxiety disorders is not accompanied by heightened autonomic responses [74]. Increased subjective stress levels due to anxiogenic drugs may not necessarily be accompanied by increased autonomic stress responsivity, which is in line with the SIH literature so far. Alternatively, the fact that stress-induced body temperatures display a consistent maximum value above which stress does not further increase body temperature may explain why the $\mathrm{SIH}$ model is less appropriate for the screening of anxiogenic properties of drugs. Moreover, bimodal influences of inverse benzodiazepines on locomotor responses have been described [77]. Therefore, inverse benzodiazepine agonists may exert increased hyperthermia or hypothermia as well depending on the dose. Further research with $\alpha$ subunit preferential inverse benzodiazepine agonists (such as $\alpha 3$ IA [71]) is needed to elucidate the exact effects of inverse benzodiazepine agonists in the SIH model.

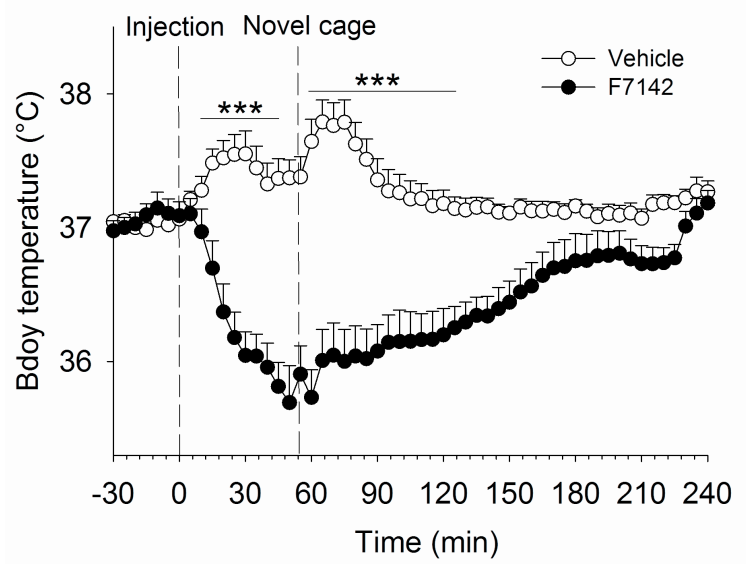

Fig. (5). Effects of $\mathrm{GABA}_{\mathrm{A}}$ receptor inverse agonist F7142 (15 $\mathrm{mg} / \mathrm{kg}$, IP) on the SIH response in Wistar rats $(\mathrm{n}=9) * * *: \mathrm{p}<0.001$.

\subsection{Other Drugs Binding to the $G A B A_{A}$ Receptor}

\subsubsection{Alcohol}

The $\mathrm{GABA}_{\mathrm{A}} \mathrm{R}$ has been implicated in the anxiolytic effects of alcohol. Generally, alcohol is thought to affect the tonic inhibition generated by extrasynaptic $\mathrm{GABA}_{\mathrm{A}} \mathrm{Rs}$ that contain $\alpha_{4}, \alpha_{6}$ and $\delta$ subunits [78], whereas modulation of synaptic $\mathrm{GABA}_{\mathrm{A}} \mathrm{Rs}$ is only present at higher concentrations [79]. However, alcohol also enhances inhibition via a $\mathrm{GABA}_{\mathrm{A}}$ ergic presynaptic mechanism in various brain areas 
including the amygdala [80]. At higher doses, alcohol can also modulate excitatory N-methyl-D-aspartic acid (NMDA) and non- NMDA glutamate receptors, serotonin and glycine receptors, as well as potassium and calcium channels [81, 82]

In the SIH model, alcohol consistently decreases the SIH response in rats as well as mice, although the effects on basal body temperature appear strain dependent (Table 5). In Fig. (6A), a typical example of the effects of alcohol on the SIH response is shown. Here, alcohol reduced the SIH response (alcohol x SIH interaction, $\mathrm{F}_{3,72}=8.58, \mathrm{p}<0.001$ ), whereas it reduced the basal body temperature at the highest dose (main alcohol effect, $F_{3,72}=10.28, p<0.001$, with Dunnett's multiple comparison as post-hoc test). Although acute administration of alcohol is known to possess an anxiolytic profile, these effects are not identical to those of classic benzodiazepines [83]. The question remains whether this putative anxiolytic alcohol effect is mediated by synaptic or extrasynaptic $\mathrm{GABA}_{\mathrm{A}} \mathrm{R}$ activation. The fact that $\delta$-subunit deficient mice demonstrate a normal anxiolytic and hypothermic response to alcohol suggests that the discussion on the (exra)synaptic mechanism by which alcohol activates the $\mathrm{GABA}_{\mathrm{A}} \mathrm{R}$ is ongoing [84].

\subsubsection{Compounds Acting on the GABA Binding Site}

Endogenous GABA can bind at two different GABA binding sites located between the $\alpha$ and $\beta \mathrm{GABA}_{\mathrm{A}} \mathrm{R}$ subunits $[95,96]$. Exogenous compounds that can bind to the same binding sites include agonists muscimol and gaboxadol as well as the antagonist bicuculline [97]. Endogenous and exogenous ligands have different affinity for the two GABA binding sites as one GABA binding site is flanked by a $\beta$ and a $\gamma$ subunit and the other by an $\alpha$ and a $\gamma$ subunit [98] (Fig. 1).

Drugs that directly act on the GABA binding site have received limited attention in the SIH model. The putative anxiolytic drug gaboxadol (THIP) has a high efficacy at extrasynaptic receptors compared to GABA $[99,100]$. The $\delta$ subunit-containing $\mathrm{GABA}_{\mathrm{A}} \mathrm{R}$ are often located extrasynaptically and perisynaptically and are thought to be involved in a continuous active inhibitory tone instead of the phasic inhibitory tone caused by intrasynaptic agonists [101, 102]. In rats, gaboxadol reduced basal body temperature and the SIH response only at the highest dose tested $(10 \mathrm{mg} / \mathrm{kg})$, whereas lower doses were ineffective [65]. The GABA binding site agonist muscimol dose-dependently reduced basal body temperature (Fig. 6B, main muscimol effect, $\mathrm{F}_{3,42}=43.34, \mathrm{p}<0.001$, with Dunnett's multiple comparison as post-hoc test) and affected the SIH response due to basal temperature lowering effects (muscimol x SIH interaction, $\left.\mathrm{F}_{3,42}=2.90, \mathrm{p}<0.05\right)$. Thus, GABA binding site agonists possess limited or no anxiolytic effect in the SIH model. The GABA binding site antagonist bicucculine did not alter the SIH response or basal body temperature (Bicucculine effect $\mathrm{F}_{3,43}=1.40, \mathrm{p}=0.26$, NS; bicucculine $\mathrm{x}$ SIH interaction $\mathrm{F}_{3,43},=1.13, \mathrm{p}=0.35$, NS), although an increased body temperature at the highest dose is apparent (Fig. 6C, unpublished results). Overall, for drugs acting at the GABA site, it seems likely that, at higher doses, agonists cause hypothermia whereas antagonists increase basal body temperature. The SIH response is generally unaffected except at high doses when interference with physiological thermoregulation occurs. So far, no clear anxiolytic effects of drugs acting at the GABA binding site have been found in the SIH model.

\subsubsection{Neurosteroids, Barbiturates and General Anesthetics}

Neurosteroids are strong and rapid potentiators of $\mathrm{GABA}_{\mathrm{A}} \mathrm{Rs}$, interacting with more than one steroid-binding site $[103,104]$. Recently, the $\mathrm{GABA}_{\mathrm{A}} \mathrm{R} \alpha_{1}$ subunit was found to be essential for the response to neurosteroids [105]. This generic pharmacological profile of neurosteroids is ascribed to a highly conserved amino acid (glutamine, Q241) in the $\mathrm{GABA}_{\mathrm{A}} \mathrm{R} \alpha$ subunits [106]. However, neursteroids have an increased potency at the $\alpha_{5}$ subunit [107] and extrasynaptic $\delta$ subunit-containing $\mathrm{GABA}_{\mathrm{A}} \mathrm{R}$ receptors [108]. No neurosteroids have been tested in the SIH model yet. The putative anxiolytic effects of neurosteroids in other studies suggest that these drugs might be effective in the SIH model $[109,110]$.

Barbiturates bind to the $\mathrm{GABA}_{\mathrm{A}} \mathrm{R}$ at the $\alpha$ subunit with distinct binding sites from the GABA and the benzodiazepine binding site [17]. Two studies found that phenobarbital was able to reduce the SIH response in mice, whereas another study that used higher doses did not find any effects (Table 5). At lower doses, barbiturates enhance GABA binding, although it potentiates $\mathrm{GABA}_{\mathrm{A}} \mathrm{Rs}$ at moderate doses in the absence of GABA, and even block $\mathrm{GABA}_{\mathrm{A}} \mathrm{Rs}$ at high doses [111]. Therefore, the anxiolytic effects of phenobarbital on the SIH response may depend on the applied dose. $\mathrm{GABA}_{\mathrm{A}} \mathrm{R}$-sensitive general anesthetics such as etomidate and propofol cause unconsciousness and immobility by acting on extrasynaptic tonic inhibitory $\alpha_{4 / 6} \beta_{3} \delta$ and $\alpha_{4} \beta_{3} \mathrm{GABA}_{\mathrm{A}}$ Rs [112]. No anxiolytic properties have been ascribed to general anesthetics, and, to our knowledge, these compounds have not been applied in the SIH model.

\section{EFFECTS OF GABA ${ }_{B}$ ERGIC DRUGS ON THE SIH RESPONSE}

Baclofen's effects on SIH have been assessed [86]. These studies show little anxiolytic effects at doses that do not alter baseline temperature. Given the ability of full $\mathrm{GABA}_{B}$ receptor agonists to produce dose-dependent mechanisticallypredicted temperature decreases [46] it is unlikely that the SIH paradigm will be sensitive enough to dissociate baseline changes in homeostatic physiology with the potential ability of full agonists to reverse stress-induced autonomic responses. Similar problems also lie with assessing the effects of other classes of ligands such as nicotine (see [8] for discussion) or certain $\mathrm{GABA}_{\mathrm{A}} \mathrm{R}$ ligands (see above; and [6]. The development of $\mathrm{GABA}_{B}$ receptor positive modulators, which on the whole have no intrinsic effects on temperature, has allowed for the contribution of $\mathrm{GABA}_{\mathrm{B}}$ receptors to the $\mathrm{SIH}$ response to be better elaborated (Table $\mathbf{6}$ ).

Initial studies characterized the effects of GS39783 on SIH where it was demonstrated that at oral doses from $0.1-$ $30 \mathrm{mg} / \mathrm{kg}$. GS39783 was able to counteract the SIH response [13] although the effect size was less than that garnered with benzodiazepines. The effects of CGP7930 on SIH were also demonstrated but these were less potent than chlordiazepoxide and that previously shown for GS39783, 

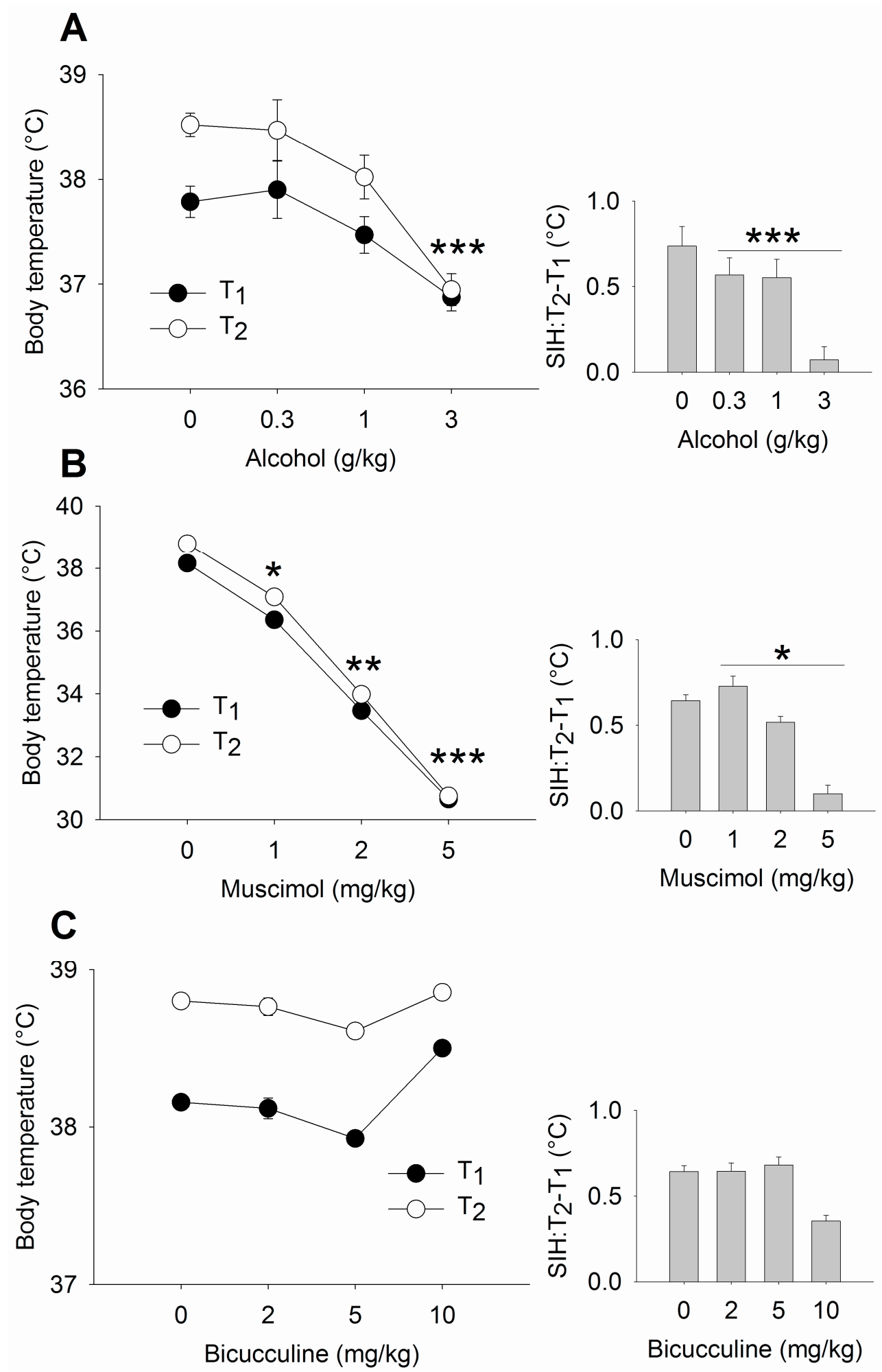

Fig. (6). Effects of $\mathrm{GABA}_{\mathrm{A}}$ receptor modulator alcohol (A), $\mathrm{GABA}_{\mathrm{A}}$ receptor GABA site agonist muscimol (B) and GABA $\mathrm{A}_{\mathrm{A}}$ receptor $\mathrm{GABA}$ site antagonist bicucculine $(\mathbf{C})$ on the SIH response in $129 \mathrm{~Sv} / \mathrm{Ev}$ mice $(\mathrm{n}=10-16){ }^{*}: \mathrm{p}<0.05 ; * *: \mathrm{p}<0.01 ; * * *: \mathrm{p}<0.001$.

with only the $100 \mathrm{mg} / \mathrm{kg}$ dose effective [55]. Interestingly, the magnitude of the effect was relatively similar between both $\mathrm{GABA}_{\mathrm{B}}$ receptor modulators. Recent studies with the novel modulator rac-BHFF (doses 3, 10, 30 and $100 \mathrm{mg} / \mathrm{kg}$, p.o.) demonstrated anxiolytic effects at all doses but with significance reached for $100 \mathrm{mg} / \mathrm{kg}$ dose only [49].
Preliminary data demonstrates that BHF177 at oral doses of 20 and $30 \mathrm{mg} / \mathrm{kg}$ displayed an anxiolytic-like SIH test in mice [50]. However, given that BHF177, at doses over 40 $\mathrm{mg} / \mathrm{kg}$ caused hypothermia - distinct from the lack of effect of other $\mathrm{GABA}_{\mathrm{B}}$ receptor positive modulators on temperature - the observed anxiolytic property in the SIH 
Table 1. Effects of Classical Benzodiazepines on the Basal Body Temperature $\left(T_{1}\right.$, Hypothermia) and the Stress-Induced Hyperthermia (SIH) Response. G-SIH: Group-House SIH Model, Including the Injection-Stressor Interval (Minutes). PO: Oral, IP: Intraperitoneal

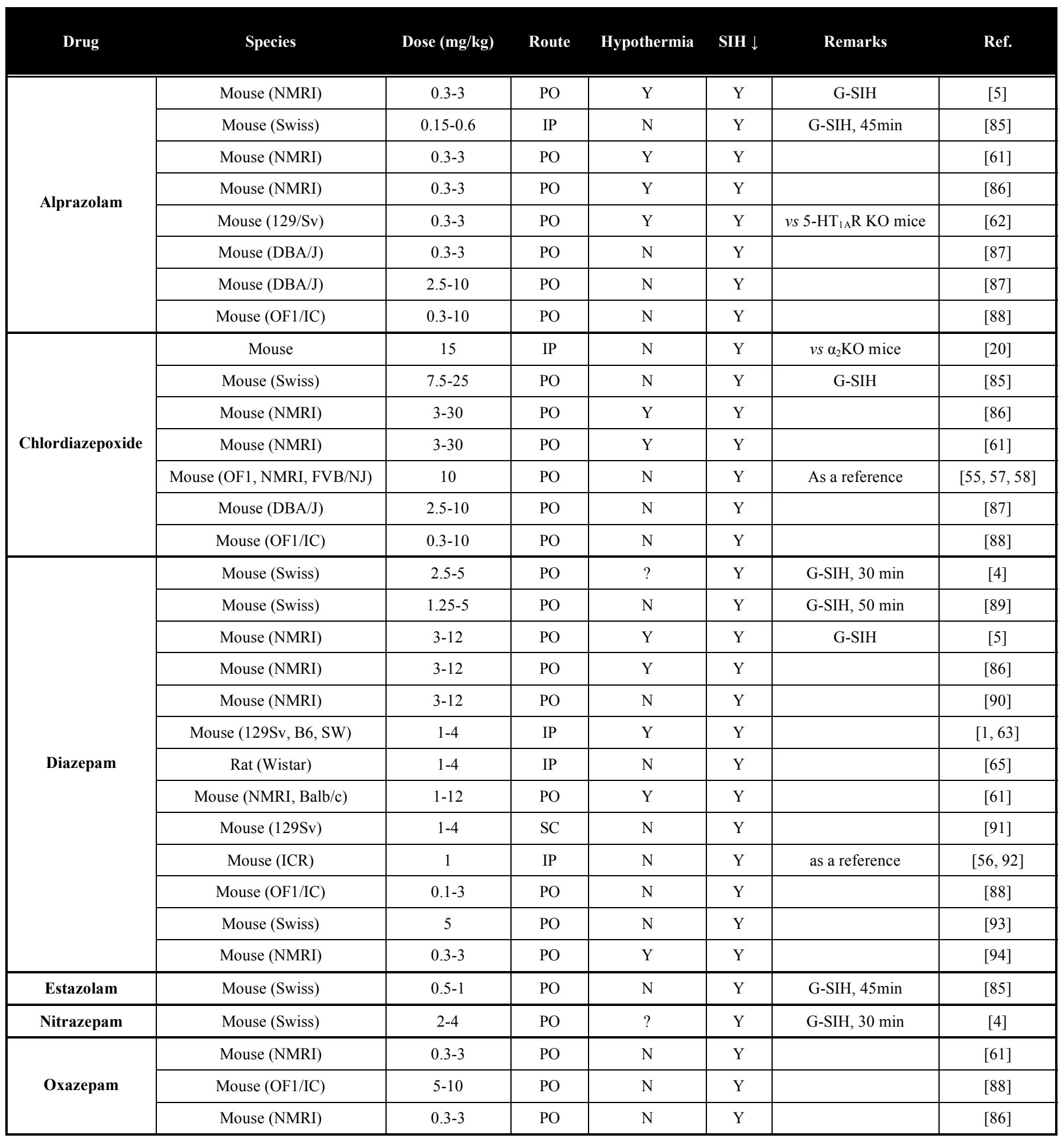

test must be viewed with caution and such effects requires further confirmation in paradigms not reliant on body temperature.

\section{CONCLUSION}

A wide variety of $\mathrm{GABA}_{\mathrm{A}}$ ergic compounds have been applied using the $\mathrm{SIH}$ paradigm, and there is overwhelming evidence that classical benzodiazepines dose-dependently reduce the $\mathrm{SIH}$ response. Subsequent studies that have applied $\mathrm{GABA}_{\mathrm{A}}$ subunit selective compounds as well as combination of agonists and antagonists have confirmed a role for the $\mathrm{GABA}_{\mathrm{A}} \mathrm{R} \alpha_{2 / 3}$ subunit in the reduction of the $\mathrm{SIH}$ response (anxiolytic effect), whereas the $\mathrm{GABA}_{\mathrm{A}} \mathrm{R} \alpha_{1}$ subunit primarily causes hypothermia. Thus, the effects of 
Table 2. Effects of Benzodiazepines Inverse Agonists and Antagonists on the Basal Body Temperature ( $T_{1}$, Hypothermia) and the Stress-Induced Hyperthermia (SIH) Response. G-SIH: Group-House SIH Model, Including the Injection-Stressor Interval (Minutes). PO: Oral, IP: Intraperitoneal

\begin{tabular}{|c|c|c|c|c|c|c|c|}
\hline Drug & Species & Dose (mg/kg) & Route & Hypothermia & $\mathbf{S I H} \downarrow$ & Remarks & Ref \\
\hline$\beta C C t$ & Rat (Wistar) & $3-20$ & IP & $\mathrm{N}$ & $\mathrm{N}$ & & {$[65]$} \\
\hline \multirow[t]{2}{*}{ Flumazenil } & Mouse (NMRI) & $1-30$ & $\mathrm{PO}$ & $\mathrm{N}$ & $\mathrm{N}$ & & [61] \\
\hline & Mouse (129Sv) & $3-30$ & SC & $\mathrm{N}$ & $\mathrm{N}$ & vs $5-\mathrm{HT}_{1 \mathrm{~A}} \mathrm{R} \mathrm{KO}$ & [62] \\
\hline FG-7142 & Rat (Wistar) & 15 & IP & $\mathrm{Y}$ & $\mathrm{Y}$ & & Present study \\
\hline \multirow{3}{*}{ Pentylenetrazole } & Mouse (NMRI) & $7.5-30$ & SC & $\mathrm{Y}$ & $\mathrm{Y}$ & $\mathrm{G}-\mathrm{SIH}$, only at $30 \mathrm{mg} / \mathrm{kg}$ & [5] \\
\hline & Mouse (NMRI) & $7.5-30$ & $\mathrm{PO}$ & $\mathrm{Y}$ & $\mathrm{N}$ & & {$[61]$} \\
\hline & Mouse (129Sv) & $7.5-30$ & $\mathrm{SC}$ & $\mathrm{Y}$ & $\mathrm{N}$ & vs $5-\mathrm{HT}_{1 \mathrm{~A}} \mathrm{R}$ KO mice & {$[62]$} \\
\hline
\end{tabular}

Table 3. Effects of Benzodiazepine Agonists (Including Combinations with Antagonists) on Basal Body Temperature ( $T_{1}$, Hypothermia) and the Stress-Induced Hyperthermia (SIH) Response. G-SIH: Group-House SIH Model, Including the Injection-Stressor Interval (Minutes). PO: Oral, IP: Intraperitoneal

\begin{tabular}{|c|c|c|c|c|c|c|c|}
\hline Drug & Species & $\begin{array}{c}\text { Dose } \\
(\mathrm{mg} / \mathrm{kg})\end{array}$ & Route & Hypothermia & SIH $\downarrow$ & Remarks & Ref. \\
\hline Alpidem & Mouse (NMRI) & $1-30$ & $\mathrm{PO}$ & Y & $\mathrm{Y}$ & & {$[61]$} \\
\hline $\begin{array}{c}\beta C C t+ \\
\text { diazepam }\end{array}$ & Rat (Wistar) & $10+4$ & IP & $\mathrm{N}$ & Y & & {$[65]$} \\
\hline $\begin{array}{c}\boldsymbol{\beta C C t}+ \\
\text { zolpidem }\end{array}$ & Rat (Wistar) & $10+10$ & IP & $\mathrm{N}$ & $\mathrm{Y}$ & & {$[65]$} \\
\hline \multirow{2}{*}{ Bretazenil } & Mouse (NMRI & $1-30$ & $\mathrm{PO}$ & $\mathrm{N}$ & $\mathrm{N}$ & & {$[61]$} \\
\hline & Mouse (129Sv/Ev) & $3-30$ & IP & $\mathrm{N}$ & $\mathrm{Y}$ & & Current study [61] \\
\hline $\begin{array}{c}\text { Flumazenil + } \\
\text { diazepam }\end{array}$ & Mouse (NMRI) & $10-30+3-6$ & $\mathrm{PO}$ & $\mathrm{N}$ & $\mathrm{Y} / \mathrm{N}$ & $\begin{array}{l}\text { Flumazenil reverses DZP } \\
\text { effects on SIH and } T_{1}\end{array}$ & {$[61]$} \\
\hline L838,417 & Mouse (129Sv, B6, SW) & $3-30$ & $\mathrm{PO}$ & $\mathrm{N}$ & $\mathrm{Y}$ & & {$[63]$} \\
\hline \multirow{2}{*}{ TP003 } & Mouse ( $\alpha 2$ and WT) & 1 & IP & $\mathrm{N}$ & Y & & [5] \\
\hline & Rat (Wistar) & $0.3-$ & IP & $\mathrm{N}$ & Y & & {$[65]$} \\
\hline \multirow{4}{*}{ Zolpidem } & Rat (Wistar) & $3-30$ & IP & $\mathrm{Y}$ & $\mathrm{Y}$ & & {$[65]$} \\
\hline & Mouse (129Sv, B6, SW) & $3-30$ & $\mathrm{PO}$ & Y & $\mathrm{Y} / \mathrm{N}$ & $\begin{array}{l}\text { No SIH reduction in } 129 \mathrm{~Sv} \\
\text { mice }\end{array}$ & {$[65]$} \\
\hline & Mouse (NMRI) & $0.3-30$ & $\mathrm{PO}$ & $\mathrm{Y}$ & $\mathrm{N}$ & Only highest dose effect on $T_{1}$ & {$[61]$} \\
\hline & Mouse (NMRI) & $0.3-30$ & $\mathrm{PO}$ & Y & $\mathrm{N}$ & Only highest dose effect on $T_{1}$ & {$[86]$} \\
\hline
\end{tabular}

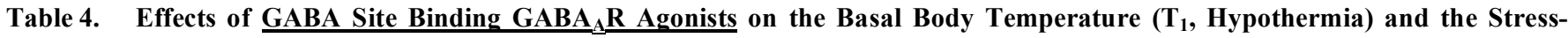
Induced Hyperthermia (SIH) Response. G-SIH: Group-House SIH Model, Including the Injection-Stressor Interval (Minutes). PO: Oral, IP: Intraperitoneal

\begin{tabular}{|c|c|c|c|c|c|c|c|}
\hline \multicolumn{1}{c}{ Drug } & Species & Dose (mg/kg) & Route & Hypothermia & SIH $\downarrow$ & \multicolumn{2}{c|}{ Remarks } \\
\hline THIP & Rat (Wistar) & $0.3-10$ & IP & Y & Y & [65] \\
\hline Muscimol & Mouse (129Sv/Ev) & $1-5$ & IP & Y & Y & Current article \\
\hline Bicucculine & Mouse (129Sv/Ev) & $2-10$ & IP & N & N & $\begin{array}{c}\text { Only at highest dose due to } \\
\text { hyperthermia }\end{array}$ & Current article \\
\hline
\end{tabular}


Table 5. Effects of GABA ${ }_{\mathrm{A}}$ Agonists Acting on other Sites than the Benzodiazepine and GABA Binding Site on the Basal Body Temperature ( $T_{1}$, Hypothermia) and the Stress-Induced Hyperthermia (SIH) Response. G-SIH: Group-House SIH Model, Including the Injection-Stressor Interval (Minutes). PO: Oral, IP: Intraperitoneal

\begin{tabular}{|c|c|c|c|c|c|c|c|}
\hline Drug & Species & Dose (mg/kg) & Route & Hypothermia & SIH $\downarrow$ & Remarks & Ref. \\
\hline \multirow{5}{*}{ Alcohol } & Rat (Wistar) & $0.3-3$ & $\mathrm{PO}$ & $\mathrm{Y}$ & $\mathrm{Y}$ & Only at $3 \mathrm{~g} / \mathrm{kg}$ & {$[65]$} \\
\hline & Mouse (Swiss) & $2-4 \mathrm{~g} / \mathrm{kg}$ & $\mathrm{PO}$ & $\mathrm{Y}$ & $\mathrm{Y}$ & G-SIH, $45 \mathrm{~min}$ & [85] \\
\hline & Mouse (NMRI) & $2-4 \mathrm{~g} / \mathrm{kg}$ & $\mathrm{PO}$ & $\mathrm{Y}$ & $\mathrm{Y}$ & Only at $4 \mathrm{~g} / \mathrm{kg}$ & [61] \\
\hline & Mouse (129Sv) & $1-4 \mathrm{~g} / \mathrm{kg}$ & $\mathrm{PO}$ & $\mathrm{N}$ & $\mathrm{Y}$ & $\mathrm{Vs} 5-\mathrm{HT}_{1 \mathrm{~A}} \mathrm{KO}$ & {$[62]$} \\
\hline & Mouse (OF1/IC) & $15-30 \%, 10 \mathrm{ml} / \mathrm{kg}$ & $\mathrm{PO}$ & $\mathrm{N}$ & $\mathrm{Y}$ & & [88] \\
\hline \multirow[b]{2}{*}{ Phenobarbital } & Mouse (NMRI) & 1 & IP & $\mathrm{N}$ & $\mathrm{Y}$ & G-SIH & [20] \\
\hline & Mouse (Swiss) & $10-20$ & IP & $\mathrm{N}$ & $\mathrm{Y}$ & G-SIH, $75 \mathrm{~min}$ & [85] \\
\hline
\end{tabular}

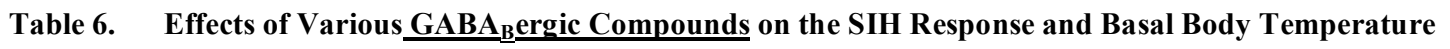

\begin{tabular}{|c|c|c|c|c|c|}
\hline Compound & Species & SIH & Hypothermia & Dose (mg/kg) & Ref \\
\hline Baclofen & Mouse & $\mathrm{N}$ & $\mathrm{Y}$ & $0-10$ & {$[86]$} \\
\hline GS39783 & Mouse & $\mathrm{Y}$ & $\mathrm{Y}$ & 0-100 PO & [13] \\
\hline rac-BHFF & Mouse & $\mathrm{Y}$ & $\mathrm{N}$ & $0-100$ & [49] \\
\hline BHF177 & Mouse & $\mathrm{Y}$ & $\mathrm{Y}$ & 0-100 PO & {$[50]$} \\
\hline
\end{tabular}

$\mathrm{GABA}_{\mathrm{A}} \mathrm{R}$ compounds on basal body temperature and the $\mathrm{SIH}$ response can be dissociated. The effects of benzodiazepine inverse agonists on the SIH response and basal body temperature are complex and remain to be elucidated. However, a clear anxiogenic effect resulting in an increased SIH response does not seem likely. Drugs that act on the GABA site of the $\mathrm{GABA}_{\mathrm{A}} \mathrm{R}$ did not result in a reduction of the $\mathrm{SIH}$ response, although all of them caused hypothermia. Whereas alcohol consistently decreases the SIH response, the effects of the barbiturate phenobarbital are not easily interpreted and might depend on the applied dose.

Although baseline temperature effects of $\mathrm{GABA}_{\mathrm{B}}$ receptor agonists preclude the drawing of any decisive conclusions on the role of this receptor in $\mathrm{SIH}$, the development of novel $\mathrm{GABA}_{\mathrm{B}}$ receptor positive modulators does indeed suggest that this receptor is a novel mechanism for counteracting SIH. To date, all of the four classes of modulators have been able to significantly counteract SIH and this paradigm is ideal for assessing the anxiolytic potential of future $\mathrm{GABA}_{\mathrm{B}}$ receptor modulators.

In conclusion, the SIH paradigm appears to be sensitive to detect the putative anxiolytic effects of GABAergic compounds acting on the $\mathrm{GABA}_{\mathrm{A}}$ and $\mathrm{GABA}_{\mathrm{B}}$ receptors in the central nervous system.

\section{REFERENCES}

[1] Vinkers, C.H.; van Bogaert, M.J.; Klanker, M.; Korte, S.M.; Oosting, R.; Hanania, T.; Hopkins, S.C.; Olivier, B.; Groenink, L. Translational aspects of pharmacological research into anxiety disorders: the stress-induced hyperthermia $(\mathrm{SIH})$ paradigm. Eur. J. Pharmacol., 2008, 585, 407-425.

[2] Renbourn, E.T. Body temperature and pulse rate in boys and young men prior to sporting contests. A study of emotional hyperthermia: with a review of the literature. J. Psychosom. Res., 1960, 4, 149175 .

[3] Kleitman, N.; Jackson, D.P. Body temperature and performance under different routines. J. Appl. Physiol., 1950, 3, 309-328.

[4] Borsini, F.; Lecci, A.; Volterra, G.; Meli, A. A model to measure anticipatory anxiety in mice? Psychopharmacology (Berl), 1989, 98, 207-211.

[5] Zethof, T.J.; Van der Heyden, J.A.; Tolboom, J.T.; Olivier, B. Stress-induced hyperthermia as a putative anxiety model. Eur. J. Pharmacol., 1995, 294, 125-135.

[6] Vinkers, C.H.; Klanker, M.; Groenink, L.; Korte, S.M.; Cook, J.M.; Van Linn, M.L.; Hopkins, S.C.; Olivier, B. Dissociating anxiolytic and sedative effects of GABAAergic drugs using temperature and locomotor responses to acute stress. Psychopharmacology (Berl), 2009, 204, 299-311.

[7] van Bogaert, M.J.; Groenink, L.; Oosting, R.S.; Westphal, K.G.; van der Gugten, J.; Olivier, B. Mouse strain differences in autonomic responses to stress. Genes Brain Behav., 2006, 5, 139 149 .

[8] Bouwknecht, J.A.; Olivier, B.; Paylor, R.E. The stress-induced hyperthermia paradigm as a physiological animal model for 
anxiety: a review of pharmacological and genetic studies in the mouse. Neurosci. Biobehav. Rev., 2007, 31, 41-59.

[9] Pirker, S.; Schwarzer, C.; Wieselthaler, A.; Sieghart, W.; Sperk, G. GABA(A) receptors: immunocytochemical distribution of 13 subunits in the adult rat brain. Neuroscience, 2000, 101, 815-850.

[10] Castelli, M.P.; Ingianni, A.; Stefanini, E.; Gessa, G.L. Distribution of $\mathrm{GABA}(\mathrm{B})$ receptor mRNAs in the rat brain and peripheral organs. Life Sci., 1999, 64, 1321-1328.

[11] Rudolph, U.; Mohler, H. GABA-based therapeutic approaches: GABAA receptor subtype functions. Curr. Opin. Pharmacol., 2006, 6, 18-23.

[12] Cryan, J.F.; Holmes, A. The ascent of mouse: advances in modelling human depression and anxiety. Nat. Rev. Drug Discov., 2005, 4, 775-790.

[13] Cryan, J.F.; Kelly, P.H.; Chaperon, F.; Gentsch, C.; Mombereau, C.; Lingenhoehl, K.; Froestl, W.; Bettler, B.; Kaupmann, K.; Spooren, W.P. Behavioral characterization of the novel GABAB receptor-positive modulator GS39783 (N,N'-dicyclopentyl-2methylsulfanyl-5-nitro-pyrimidine-4,6-diamine): anxiolytic-like activity without side effects associated with baclofen or benzodiazepines. J. Pharmacol. Exp. Ther., 2004, 310, 952-963.

[14] Wisden, W.; Laurie, D.J.; Monyer, H.; Seeburg, P.H. The distribution of 13 GABAA receptor subunit mRNAs in the rat brain. I. Telencephalon, diencephalon, mesencephalon. $J$. Neurosci., 1992, 12, 1040-1062.

[15] Sibille, E.; Pavlides, C.; Benke, D.; Toth, M. Genetic inactivation of the Serotonin(1A) receptor in mice results in downregulation of major $\mathrm{GABA}(\mathrm{A})$ receptor alpha subunits, reduction of $\mathrm{GABA}(\mathrm{A})$ receptor binding, and benzodiazepine-resistant anxiety. $J$. Neurosci., 2000, 20, 2758-2765.

[16] Benke, D.; Fakitsas, P.; Roggenmoser, C.; Michel, C.; Rudolph, U.; Mohler, H. Analysis of the presence and abundance of GABAA receptors containing two different types of alpha subunits in murine brain using point-mutated alpha subunits. J. Biol. Chem., 2004, 279, 43654-43660.

[17] Sieghart, W. Structure and pharmacology of gamma-aminobutyric acidA receptor subtypes. Pharmacol. Rev., 1995, 47, 181-234.

[18] Rudolph, U.; Crestani, F.; Benke, D.; Brunig, I.; Benson, J.A.; Fritschy, J.M.; Martin, J.R.; Bluethmann, H.; Mohler, H. Benzodiazepine actions mediated by specific gamma-aminobutyric acid(A) receptor subtypes. Nature, 1999, 401, 796-800.

[19] Crestani, F.; Low, K.; Keist, R.; Mandelli, M.; Mohler, H.; Rudolph, U. Molecular targets for the myorelaxant action of diazepam. Mol. Pharmacol., 2001, 59, 442-445.

[20] Dias, R.; Sheppard, W.F.; Fradley, R.L.; Garrett, E.M.; Stanley, J.L.; Tye, S.J.; Goodacre, S.; Lincoln, R.J.; Cook, S.M.; Conley, R.; Hallett, D.; Humphries, A.C.; Thompson, S.A.; Wafford, K.A.; Street, L.J.; Castro, J.L.; Whiting, P.J.; Rosahl, T.W.; Atack, J.R.; McKernan, R.M.; Dawson, G.R.; Reynolds, D.S. Evidence for a significant role of alpha 3-containing GABAA receptors in mediating the anxiolytic effects of benzodiazepines. J. Neurosci., 2005, 25, 10682-10688.

[21] McKernan, R.M.; Rosahl, T.W.; Reynolds, D.S.; Sur, C.; Wafford, K.A.; Atack, J.R.; Farrar, S.; Myers, J.; Cook, G.; Ferris, P.; Garrett, L.; Bristow, L.; Marshall, G.; Macaulay, A.; Brown, N.; Howell, O.; Moore, K.W.; Carling, R.W.; Street, L.J.; Castro, J.L.; Ragan, C.I.; Dawson, G.R.; Whiting, P.J. Sedative but not anxiolytic properties of benzodiazepines are mediated by the GABA(A) receptor alpha1 subtype. Nat. Neurosci., 2000, 3, 587592.

[22] Low, K.; Crestani, F.; Keist, R.; Benke, D.; Brunig, I.; Benson, J.A.; Fritschy, J.M.; Rulicke, T.; Bluethmann, H.; Mohler, H.; Rudolph, U. Molecular and neuronal substrate for the selective attenuation of anxiety. Science, 2000, 290, 131-134.

[23] van Steveninck, A.L.; Gieschke, R.; Schoemaker, R.C.; Roncari, G.; Tuk, B.; Pieters, M.S.; Breimer, D.D.; Cohen, A.F. Pharmacokinetic and pharmacodynamic interactions of bretazenil and diazepam with alcohol. Br. J. Clin. Pharmacol., 1996, 41, 565573.

[24] Lippa, A.; Czobor, P.; Stark, J.; Beer, B.; Kostakis, E.; Gravielle, M.; Bandyopadhyay, S.; Russek, S.J.; Gibbs, T.T.; Farb, D.H.; Skolnick, P. Selective anxiolysis produced by ocinaplon, a GABA(A) receptor modulator. Proc. Natl. Acad. Sci. USA, 2005, 102, 7380-7385

[25] Popik, P.; Kostakis, E.; Krawczyk, M.; Nowak, G.; Szewczyk, B.; Krieter, P.; Chen, Z.; Russek, S.J.; Gibbs, T.T.; Farb, D.H.;
Skolnick, P.; Lippa, A.S.; Basile, A.S. The anxioselective agent $7-$ (2-chloropyridin-4-yl)pyrazolo-[1,5-a]-pyrimidin-3-yl](pyridin-2yl)meth anone (DOV 51892) is more efficacious than diazepam at enhancing GABA-gated currents at alpha1 subunit-containing GABAA receptors. J. Pharmacol. Exp. Ther., 2006, 319, 12441252

[26] Wafford, K.A.; Whiting, P.J.; Kemp, J.A. Differences in affinity and efficacy of benzodiazepine receptor ligands at recombinant gamma-aminobutyric acidA receptor subtypes. Mol. Pharmacol., 1993, 43, 240-244

[27] Graham, N.M.; Burrell, C.J.; Douglas, R.M.; Debelle, P.; Davies, L. Adverse effects of aspirin, acetaminophen, and ibuprofen on immune function, viral shedding, and clinical status in rhinovirusinfected volunteers. J. Infect. Dis., 1990, 162, 1277-1282.

[28] Calver, A.R.; Davies, C.H.; Pangalos, M. GABA(B) receptors: from monogamy to promiscuity. Neurosignals, 2002, 11, 299-314.

[29] Bettler, B.; Kaupmann, K.; Mosbacher, J.; Gassmann, M. Molecular structure and physiological functions of $\operatorname{GABA}(\mathrm{B})$ receptors. Physiol. Rev., 2004, 84, 835-867.

[30] Cryan, J.F.; Kaupmann, K. Don't worry 'B' happy!: a role for GABA(B) receptors in anxiety and depression. Trends Pharmacol. Sci., 2005, 26, 36-43.

[31] Drake, R.G.; Davis, L.L.; Cates, M.E.; Jewell, M.E.; Ambrose, S.M.; Lowe, J.S. Baclofen treatment for chronic posttraumatic stress disorder. Ann. Pharmacother., 2003, 37, 1177-1181.

[32] Addolorato, G.; Caputo, F.; Capristo, E.; Domenicali, M.; Bernardi, M.; Janiri, L.; Agabio, R.; Colombo, G.; Gessa, G.L.; Gasbarrini, G. Baclofen efficacy in reducing alcohol craving and intake: a preliminary double-blind randomized controlled study. Alcohol Alcohol, 2002, 37, 504-508.

[33] Addolorato, G.; Leggio, L.; Abenavoli, L.; Agabio, R.; Caputo, F.; Capristo, E.; Colombo, G.; Gessa, G.L.; Gasbarrini, G. Baclofen in the treatment of alcohol withdrawal syndrome: a comparative study vs diazepam. Am. J. Med., 2006, 119, 276 e13-18.

[34] Breslow, M.F.; Fankhauser, M.P.; Potter, R.L.; Meredith, K.E.; Misiaszek, J.; Hope, D.G., Jr. Role of gamma-aminobutyric acid in antipanic drug efficacy. Am. J. Psychiatry, 1989, 146, 353-356.

[35] Hinderer, S.R. The supraspinal anxiolytic effect of baclofen for spasticity reduction. Am. J. Phys. Med. Rehabil., 1990, 69, 254258 .

[36] Nastiti, K.; Benton, D.; Brain, P.F. The effects of compounds acting at the benzodiazepine receptor complex on the ultrasonic calling of mouse pups. Behav. Pharmacol., 1991, 2, 121-128.

[37] Shephard, R.A.; Wedlock, P.; Wilson, N.E. Direct evidence for mediation of an anticonflict effect of baclofen by GABAb receptors. Pharmacol. Biochem. Behav., 1992, 41, 651-653.

[38] Andrews, N.; File, S.E. Handling history of rats modifies behavioural effects of drugs in the elevated plus-maze test of anxiety. Eur. J. Pharmacol., 1993, 235, 109-112.

[39] Dalvi, A.; Rodgers, R.J. GABAergic influences on plus-maze behaviour in mice. Psychopharmacology (Berl), 1996, 128, 380397.

[40] File, S.E.; Zharkovsky, A.; Gulati, K. Effects of baclofen and nitrendipine on ethanol withdrawal responses in the rat. Neuropharmacology, 1991, 30, 183-190.

[41] File, S.E.; Mabbutt, P.S.; Andrews, N. Diazepam withdrawal responses measured in the social interaction test of anxiety and their reversal by baclofen. Psychopharmacology (Berl), 1991, 104, 62-66.

[42] File, S.E.; Andrews, N.; Wu, P.Y.; Zharkovsky, A.; Zangrossi, H., Jr. Modification of chlordiazepoxide's behavioural and neurochemical effects by handling and plus-maze experience. Eur. J. Pharmacol., 1992, 218, 9-14.

[43] Mombereau, C.; Kaupmann, K.; Froestl, W.; Sansig, G.; van der Putten, H.; Cryan, J.F. Genetic and pharmacological evidence of a role for GABA(B) receptors in the modulation of anxiety- and antidepressant-like behavior. Neuropsychopharmacology, 2004, 29, 1050-1062.

[44] Mombereau, C.; Kaupmann, K.; Gassmann, M.; Bettler, B.; van der Putten, H.; Cryan, J.F. Altered anxiety and depression-related behaviour in mice lacking $\mathrm{GABAB}(2)$ receptor subunits. Neuroreport, 2005, 16, 307-310.

[45] Shaban, H.; Humeau, Y.; Herry, C.; Cassasus, G.; Shigemoto, R.; Ciocchi, S.; Barbieri, S.; van der Putten, H.; Kaupmann, K.; Bettler, B.; Luthi, A. Generalization of amygdala LTP and 
conditioned fear in the absence of presynaptic inhibition. Nat. Neurosci., 2006, 9(8), 1028-1035.

[46] Jacobson, L.H.; Cryan, J.F. Differential sensitivity to the motor and hypothermic effects of the GABA B receptor agonist baclofen in various mouse strains. Psychopharmacology (Berl), 2005, 179, 688-699.

[47] Urwyler, S.; Mosbacher, J.; Lingenhoehl, K.; Heid, J.; Hofstetter, K.; Froestl, W.; Bettler, B.; Kaupmann, K. Positive allosteric modulation of native and recombinant gamma-aminobutyric acid(B) receptors by 2,6-Di-tert-butyl-4-(3-hydroxy-2,2-dimethylpropyl)-phenol (CGP7930) and its aldehyde analog CGP13501. Mol. Pharmacol., 2001, 60,963-971.

[48] Urwyler, S.; Pozza, M.F.; Lingenhoehl, K.; Mosbacher, J.; Lampert, C.; Froestl, W.; Koller, M.; Kaupmann, K. N,N'Dicyclopentyl-2-methylsulfanyl-5-nitro-pyrimidine-4,6-diamine (GS39783) and structurally related compounds: novel allosteric enhancers of gamma-aminobutyric acidB receptor function. $J$. Pharmacol. Exp. Ther., 2003, 307, 322-330.

[49] Malherbe, P.; Masciadri, R.; Norcross, R.D.; Knoflach, F.; Kratzeisen, C.; Zenner, M.T.; Kolb, Y.; Marcuz, A.; Huwyler, J.; Nakagawa, T.; Porter, R.H.; Thomas, A.W.; Wettstein, J.G.; Sleight, A.J.; Spooren, W.; Prinssen, E.P. Characterization of (R,S)-5,7-di-tert-butyl-3-hydroxy-3-trifluoromethyl-3H-

benzofuran-2-one as a positive allosteric modulator of GABAB receptors. Br. J. Pharmacol., 2008, 154, 797-811.

[50] Jacobson, L.H.; Guery, S.; Froestl, W.; Gentsch, C.; Enz, A.; Cryan, J.F.; Kaupmann, K. In vitro and in vivo characterization of a novel GABAB receptor positive allosteric modulator. Program No 824.5. Neuroscience meeting planner, Washington, DC, Society for Neuroscience $\mathbf{2 0 0 8 .}$

[51] Paterson, N.E.; Vlachou, S.; Guery, S.; Kaupmann, K.; Froestl, W.; Markou, A. Positive modulation of GABA(B) receptors decreased nicotine self-administration and counteracted nicotine-induced enhancement of brain reward function in rats. J. Pharmacol. Exp. Ther., 2008, 326, 306-314.

[52] Dupuis, D.S.; Relkovic, D.; Lhuillier, L.; Mosbacher, J.; Kaupmann, K. Point mutations in the transmembrane region of GABAB2 facilitate activation by the positive modulator N,N'dicyclopentyl-2-methylsulfanyl-5-nitro-pyrimidine-4,6-diamine (GS39783) in the absence of the GABAB1 subunit. Mol. Pharmacol., 2006, 70, 2027-2036.

[53] Carai, M.A.; Colombo, G.; Froestl, W.; Gessa, G.L. In vivo effectiveness of CGP7930, a positive allosteric modulator of the GABAB receptor. Eur. J. Pharmacol., 2004, 504, 213-216.

[54] Gjoni, T.; Desrayaud, S.; Imobersteg, S.; Urwyler, S. The positive allosteric modulator GS39783 enhances GABA(B) receptormediated inhibition of cyclic AMP formation in rat striatum in vivo. J. Neurochem., 2006, 96, 1416-1422.

[55] Jacobson, L.H.; Cryan, J.F. Evaluation of the anxiolytic-like profile of the GABAB receptor positive modulator CGP7930 in rodents. Neuropharmacology, 2008, 54, 854-862.

[56] Iijima, M.; Shimazaki, T.; Ito, A.; Chaki, S. Effects of metabotropic glutamate $2 / 3$ receptor antagonists in the stress-induced hyperthermia test in singly housed mice. Psychopharmacology (Berl), 2007, 190, 233-239.

[57] Stemmelin, J.; Cohen, C.; Terranova, J.P.; Lopez-Grancha, M.; Pichat, P.; Bergis, O.; Decobert, M.; Santucci, V.; Francon, D.; Alonso, R.; Stahl, S.M.; Keane, P.; Avenet, P.; Scatton, B.; le Fur, G.; Griebel, G. Stimulation of the beta3-Adrenoceptor as a novel treatment strategy for anxiety and depressive disorders. Neuropsychopharmacology, 2008, 33, 574-587.

[58] Nordquist, R.E.; Durkin, S.; Jaeschke, G.; Spooren, W. Stressinduced hyperthermia: effects of acute and repeated dosing of MPEP. Eur. J. Pharmacol., 2007, 568, 199-202.

[59] Pritchett, D.B.; Luddens, H.; Seeburg, P.H. Type I and type II GABAA-benzodiazepine receptors produced in transfected cells. Science, 1989, 245, 1389-1392.

[60] Pritchett, D.B.; Seeburg, P.H. Gamma-aminobutyric acidA receptor alpha 5-subunit creates novel type II benzodiazepine receptor pharmacology. J. Neurochem., 1990, 54, 1802-1804.

[61] Olivier, B.; Bouwknecht, J.A.; Pattij, T.; Leahy, C.; van Oorschot, R.; Zethof, T.J. GABAA-benzodiazepine receptor complex ligands and stress-induced hyperthermia in singly housed mice. Pharmacol. Biochem. Behav., 2002, 72, 179-188.

[62] Pattij, T.; Groenink, L.; Oosting, R.S.; van der Gugten, J.; Maes, R.A.; Olivier, B. GABA(A)-benzodiazepine receptor complex sensitivity in 5-HT(1A) receptor knockout mice on a $129 / \mathrm{Sv}$ background. Eur. J. Pharmacol., 2002, 447, 67-74.

[63] Van Bogaert, M.; Oosting, R.; Toth, M.; Groenink, L.; van Oorschot, R.; Olivier, B. Effects of genetic background and null mutation of 5-HT1A receptors on basal and stress-induced body temperature: modulation by serotonergic and GABAA-ergic drugs. Eur. J. Pharmacol., 2006, 550, 84-90.

[64] Ebert, B.; Wafford, K.A.; Deacon, S. Treating insomnia: Current and investigational pharmacological approaches. Pharmacol. Ther., 2006, 112, 612-629.

[65] Vinkers, C.H.; Klanker, M.; Groenink, L.; Korte, S.M.; Cook, J.M.; Van Linn, M.L.; Hopkins, S.C.; Olivier, B. Dissociating anxiolytic and sedative effects of GABA(A)ergic drugs using temperature and locomotor responses to acute stress. Psychopharmacology (Berl), 2009.

[66] Atack, J.R.; Smith, A.J.; Emms, F.; McKernan, R.M. Regional differences in the inhibition of mouse in vivo [3H]Ro 15-1788 binding reflect selectivity for alpha 1 vs alpha 2 and alpha 3 subunit-containing GABAA receptors. Neuropsychopharmacology, 1999, 20, 255-262.

[67] Collinson, N.; Kuenzi, F.M.; Jarolimek, W.; Maubach, K.A.; Cothliff, R.; Sur, C.; Smith, A.; Otu, F.M.; Howell, O.; Atack, J.R.; McKernan, R.M.; Seabrook, G.R.; Dawson, G.R.; Whiting, P.J.; Rosahl, T.W. Enhanced learning and memory and altered GABAergic synaptic transmission in mice lacking the alpha 5 subunit of the GABAA receptor. J. Neurosci., 2002, 22, 55725580 .

[68] Dawson, G.R.; Maubach, K.A.; Collinson, N.; Cobain, M.; Everitt, B.J.; MacLeod, A.M.; Choudhury, H.I.; McDonald, L.M.; Pillai, G.; Rycroft, W.; Smith, A.J.; Sternfeld, F.; Tattersall, F.D.; Wafford, K.A.; Reynolds, D.S.; Seabrook, G.R.; Atack, J.R. An inverse agonist selective for alpha5 subunit-containing GABAA receptors enhances cognition. J. Pharmacol. Exp. Ther., 2006, 316, 1335-1345.

[69] Potier, M.C.; Prado de Carvalho, L.; Venault, P.; Chapouthier, G.; Rossier, J. Demonstration of the partial agonist profiles of Ro 166028 and Ro 17-1812 in mice in vivo. Eur. J. Pharmacol., 1988, $156,169-172$.

[70] Huang, Q.; He, X.; Ma, C.; Liu, R.; Yu, S.; Dayer, C.A.; Wenger, G.R.; McKernan, R.; Cook, J.M. Pharmacophore/receptor models for $\mathrm{GABA}(\mathrm{A}) / \mathrm{BzR}$ subtypes (alpha1beta3gamma2, alpha5beta3gamma2, and alpha6beta3gamma2) via a comprehensive ligand-mapping approach. J. Med. Chem., 2000, 43, 71-95.

[71] Atack, J.R.; Hutson, P.H.; Collinson, N.; Marshall, G.; Bentley, G.; Moyes, C.; Cook, S.M.; Collins, I.; Wafford, K.; McKernan, R.M.; Dawson, G.R. Anxiogenic properties of an inverse agonist selective for alpha3 subunit-containing GABA A receptors. $\mathrm{Br} . \mathrm{J}$. Pharmacol., 2005, 144, 357-366.

[72] File, S.E.; Baldwin, H.A. Effects of beta-carbolines in animal models of anxiety. Brain Res. Bull., 1987, 19, 293-299.

[73] Hofmann, S.G.; Newman, M.G.; Ehlers, A.; Roth, W.T. Psychophysiological differences between subgroups of social phobia. J. Abnorm. Psychol., 1995, 104, 224-231.

[74] Hoehn-Saric, R.; McLeod, D.R.; Funderburk, F.; Kowalski, P. Somatic symptoms and physiologic responses in generalized anxiety disorder and panic disorder: an ambulatory monitor study. Arch. Gen. Psychiatry, 2004, 61, 913-921.

[75] van der Wee, N.J.; Fiselier, J.; van Megen, H.J.; Westenberg, H.G. Behavioural effects of rapid intravenous administration of metachlorophenylpiperazine in patients with panic disorder and controls. Eur. Neuropsychopharmacol., 2004, 14, 413-417.

[76] Van Veen, J.F.; Van der Wee, N.J.; Fiselier, J.; Van Vliet, I.M.; Westenberg, H.G. Behavioural effects of rapid intravenous administration of meta-chlorophenylpiperazine (m-CPP) in patients with generalized social anxiety disorder, panic disorder and healthy controls. Eur. Neuropsychopharmacol., 2007, 17, 637-642.

[77] Savic, M.M.; Obradovic, D.I.; Ugresic, N.D.; Cook, J.M.; Yin, W.; Van Linn, M.; Bokonjic, D.R. Benzodiazepine site inverse agonists and locomotor activity in rats: bimodal and biphasic influence. Pharmacol. Biochem. Behav., 2006, 84, 35-42.

[78] Wallner, M.; Olsen, R.W. Physiology and pharmacology of alcohol: the imidazobenzodiazepine alcohol antagonist site on subtypes of GABAA receptors as an opportunity for drug development? Br. J. Pharmacol., 2008, 154, 288-298. 
[79] Jia, F.; Chandra, D.; Homanics, G.E.; Harrison, N.L. Ethanol modulates synaptic and extrasynaptic GABAA receptors in the thalamus. J. Pharmacol. Exp. Ther., 2008, 326, 475-482.

[80] Roberto, M.; Madamba, S.G.; Moore, S.D.; Tallent, M.K.; Siggins, G.R. Ethanol increases GABAergic transmission at both pre- and postsynaptic sites in rat central amygdala neurons. Proc. Natl. Acad. Sci. USA, 2003, 100, 2053-2058.

[81] Dopico, A.M.; Lovinger, D.M. Acute alcohol action and desensitization of ligand-gated ion channels. Pharmacol. Rev., 2009, 61, 98-114.

[82] Harris, R.A. Ethanol actions on multiple ion channels: which are important? Alcohol Clin. Exp. Res., 1999, 23, 1563-1570.

[83] Langen, B.; Dietze, S.; Fink, H. Acute effect of ethanol on anxiety and 5-HT in the prefrontal cortex of rats. Alcohol, 2002, 27, 135141.

[84] Mihalek, R.M.; Banerjee, P.K.; Korpi, E.R.; Quinlan, J.J.; Firestone, L.L.; Mi, Z.P.; Lagenaur, C.; Tretter, V.; Sieghart, W.; Anagnostaras, S.G.; Sage, J.R.; Fanselow, M.S.; Guidotti, A.; Spigelman, I.; Li, Z.; DeLorey, T.M.; Olsen, R.W.; Homanics, G.E. Attenuated sensitivity to neuroactive steroids in gammaaminobutyrate type A receptor delta subunit knockout mice. Proc. Natl. Acad. Sci. USA, 1999, 96, 12905-12910.

[85] Lecci, A.; Borsini, F.; Volterra, G.; Meli, A. Pharmacological validation of a novel animal model of anticipatory anxiety in mice. Psychopharmacology (Berl), 1990, 101, 255-261.

[86] Olivier, B.; Zethof, T.; Pattij, T.; van Boogaert, M.; van Oorschot, R.; Leahy, C.; Oosting, R.; Bouwknecht, A.; Veening, J.; van der Gugten, J.; Groenink, L. Stress-induced hyperthermia and anxiety: pharmacological validation. Eur. J. Pharmacol., 2003, 463, 117132.

[87] Rorick-Kehn, L.M.; Hart, J.C.; McKinzie, D.L. Pharmacological characterization of stress-induced hyperthermia in DBA/2 mice using metabotropic and ionotropic glutamate receptor ligands. Psychopharmacology (Berl), 2005, 183, 226-240.

[88] Spooren, W.P.; Schoeffter, P.; Gasparini, F.; Kuhn, R.; Gentsch, C. Pharmacological and endocrinological characterisation of stressinduced hyperthermia in singly housed mice using classical and candidate anxiolytics (LY314582, MPEP and NKP608). Eur. $J$. Pharmacol., 2002, 435, 161-170.

[89] Chen, S.W.; Xin, Q.; Kong, W.X.; Min, L.; Li, J.F. Anxiolytic-like effect of succinic acid in mice. Life Sci., 2003, 73, 3257-3264.

[90] Groenink, L.; van der Gugten, J.; Zethof, T.J.; van der Heyden, J.A.; Olivier, B. Neuroendocrine effects of diazepam and flesinoxan in the stress-induced hyperthermia test in mice. Pharmacol. Biochem. Behav., 1996, 54, 249-254.

[91] Pattij, T.; Hijzen, T.H.; Groenink, L.; Oosting, R.S.; van der Gugten, J.; Maes, R.A.; Hen, R.; Olivier, B. Stress-induced hyperthermia in the 5-HT(1A) receptor knockout mouse is normal. Biol. Psychiatry, 2001, 49, 569-574.

[92] Satow, A.; Maehara, S.; Ise, S.; Hikichi, H.; Fukushima, M.; Suzuki, G.; Kimura, T.; Tanak, T.; Ito, S.; Kawamoto, H.; Ohta, H. Pharmacological effects of the metabotropic glutamate receptor 1 antagonist compared with those of the metabotropic glutamate receptor 5 antagonist and metabotropic glutamate receptor $2 / 3$ agonist in rodents: detailed investigations with a selective allosteric metabotropic glutamate receptor 1 antagonist, FTIDC [4-[1-(2fluoropyridine-3-yl)-5-methyl-1H-1,2,3-triazol-4-yl]-N-isopropylN-methyl-3,6-dihydropyridine-1(2H)-carboxamide]. J. Pharmacol. Exp. Ther., 2008, 326, 577-586.

[93] Chen, S.W.; Min, L.; Li, W.J.; Kong, W.X.; Li, J.F.; Zhang, Y.J. The effects of angelica essential oil in three murine tests of anxiety. Pharmacol. Biochem. Behav., 2004, 79, 377-382.
[94] Van der Heyden, J.A.; Zethof, T.J.; Olivier, B. Stress-induced hyperthermia in singly housed mice. Physiol. Behav., 1997, 62, 463-470.

[95] Amin, J.; Weiss, D.S. GABAA receptor needs two homologous domains of the beta-subunit for activation by GABA but not by pentobarbital. Nature, 1993, 366, 565-569.

[96] Boileau, A.J.; Evers, A.R.; Davis, A.F.; Czajkowski, C. Mapping the agonist binding site of the GABAA receptor: evidence for a beta-strand. J. Neurosci., 1999, 19, 4847-4854.

[97] Ebert, B.; Wafford, K.A.; Whiting, P.J.; Krogsgaard-Larsen, P.; Kemp, J.A. Molecular pharmacology of gamma-aminobutyric acid type A receptor agonists and partial agonists in oocytes injected with different alpha, beta, and gamma receptor subunit combinations. Mol. Pharmacol., 1994, 46, 957-963.

[98] Baumann, S.W.; Baur, R.; Sigel, E. Individual properties of the two functional agonist sites in GABA(A) receptors. J. Neurosci., 2003, 23, 11158-11166.

[99] Wafford, K.A.; Ebert, B. Gaboxadol--a new awakening in sleep. Curr. Opin. Pharmacol., 2006, 6, 30-36.

[100] Saarelainen, K.S.; Ranna, M.; Rabe, H.; Sinkkonen, S.T.; Moykkynen, T.; Uusi-Oukari, M.; Linden, A.M.; Luddens, H.; Korpi, E.R. Enhanced behavioral sensitivity to the competitive GABA agonist, gaboxadol, in transgenic mice over-expressing hippocampal extrasynaptic alpha6beta $\operatorname{GABA}(\mathrm{A})$ receptors. $J$. Neurochem., 2008, 105, 338-350.

[101] Farrant, M.; Nusser, Z. Variations on an inhibitory theme: phasic and tonic activation of GABA(A) receptors. Nat. Rev. Neurosci., 2005, 6, 215-229.

[102] Nusser, Z.; Sieghart, W.; Somogyi, P. Segregation of different GABAA receptors to synaptic and extrasynaptic membranes of cerebellar granule cells. J. Neurosci., 1998, 18, 1693-1703.

[103] Akk, G.; Li, P.; Bracamontes, J.; Reichert, D.E.; Covey, D.F.; Steinbach, J.H. Mutations of the GABA-A receptor alpha1 subunit M1 domain reveal unexpected complexity for modulation by neuroactive steroids. Mol. Pharmacol., 2008, 74, 614-627.

[104] Hosie, A.M.; Wilkins, M.E.; Smart, T.G. Neurosteroid binding sites on GABA(A) receptors. Pharmacol. Ther., 2007, 116, 7-19.

[105] Akk, G.; Li, P.; Bracamontes, J.; Steinbach, J.H. Activation and modulation of concatemeric GABA-A receptors expressed in human embryonic kidney cells. Mol. Pharmacol., 2009, 75(6), $1400-1411$

[106] Hosie, A.M.; Clarke, L.; da Silva, H.; Smart, T.G. Conserved site for neurosteroid modulation of GABA A receptors. Neuropharmacology, 2009, 56, 149-154.

[107] Rahman, M.; Lindblad, C.; Johansson, I.M.; Backstrom, T.; Wang, M.D. Neurosteroid modulation of recombinant rat alpha5beta2gamma2L and alpha1beta2gamma2L GABA(A) receptors in Xenopus oocyte. Eur. J. Pharmacol., 2006, 547, 37-44.

[108] Belelli, D.; Lambert, J.J. Neurosteroids: endogenous regulators of the GABA(A) receptor. Nat. Rev. Neurosci., 2005, 6, 565-575.

[109] Crawley, J.N.; Glowa, J.R.; Majewska, M.D.; Paul, S.M. Anxiolytic activity of an endogenous adrenal steroid. Brain Res., 1986, 398, 382-385.

[110] Bitran, D.; Hilvers, R.J.; Kellogg, C.K. Anxiolytic effects of 3 alpha-hydroxy-5 alpha[beta]-pregnan-20-one: endogenous metabolites of progesterone that are active at the GABAA receptor. Brain Res., 1991, 561, 157-161.

[111] Steinbach, J.H.; Akk, G. Modulation of GABA(A) receptor channel gating by pentobarbital. J. Physiol., 2001, 537 (Pt 3), 715-733.

[112] Meera, P.; Olsen, R.W.; Otis, T.S.; Wallner, M. Etomidate, propofol and the neurosteroid THDOC increase the GABA efficacy of recombinant alpha4beta3delta and alpha4beta3 GABA A receptors expressed in HEK cells. Neuropharmacology, 2009, 56, 155-160. 